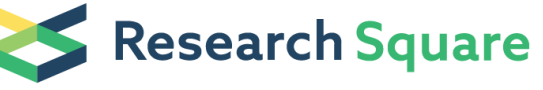 \\ Preprints are preliminary reports that have not undergone peer review. \\ They should not be considered conclusive, used to inform clinical practice, \\ or referenced by the media as validated information.
}

\section{Selective catalysis remedies polysulfide shuttling in lithium-sulfur batteries}

\section{Wuxing Hua}

School of Chemical Engineering and Technology, Tianjin University, Tianjin 300072, China

\section{Huan Li}

School of Chemical Engineering and Advanced Materials, The University of Adelaide, Adelaide, SA 5005, Australia;

\section{Chun Pei}

Key Laboratory of Resource Chemistry of Ministry of Education, Shanghai Key Laboratory of Rare Earth Functional Materials, Department of Chemistry, Shanghai Normal University, Shanghai 200234, China Jingyi Xia

School of Chemical Engineering and Technology, Tianjin University, Tianjin 300072, China

\section{Yafei Sun}

Shanghai Normal University

\section{Chen Zhang}

Tianjin University

\section{Wei LV}

Tsinghua University

\section{Ying Tao}

Nanoyang Group, State Key Laboratory of Chemical Engineering, School of Chemical Engineering and Technology, Tianjin University, Tianjin 300072, China

\section{Yan Jiao}

The University of Adelaide https://orcid.org/0000-0003-1329-4290

\section{Bingsen Zhang}

Institute of Metal Research, Chinese Academy of Sciences https://orcid.org/0000-0002-2607-2999

\section{Shizhang Qiao}

University of Adelaide https://orcid.org/0000-0002-4568-8422

\section{Ying Wan}

Shanghai Normal University https://orcid.org/0000-0002-6898-6748

\section{Quan-Hong Yang ( $\square$ qhyangcn@tju.edu.cn )}

School of Chemical Engineering and Technology, Tianjin University, Tianjin 300072, China

\section{Article}


Keywords: polysulfide shuttling, lithium-sulfur batteries, catalysis

Posted Date: December 1st, 2020

DOI: https://doi.org/10.21203/rs.3.rs-98178/v1

License: (c) (1) This work is licensed under a Creative Commons Attribution 4.0 International License. Read Full License

Version of Record: A version of this preprint was published at Advanced Materials on August 2nd, 2021. See the published version at https://doi.org/10.1002/adma.202101006. 


\section{in lithium-sulfur batteries}

Wuxing Hua ${ }^{1,2 \dagger}$, Huan $\mathrm{Li}^{3 \dagger}$, Chun Pei ${ }^{2 \dagger}$, Jingyi Xia ${ }^{1}$, Yafei Sun${ }^{2}$, Chen Zhang ${ }^{4}$, Wei Lv ${ }^{5}$, Ying Tao',

Yan Jiao ${ }^{3}$, Bingsen Zhang ${ }^{6}$, Shi-Zhang Qiao ${ }^{3}$, Ying Wan ${ }^{2 *}$ and Quan-Hong Yang ${ }^{1 *}$

The shuttling of soluble lithium polysulfides between the electrodes leads to serious capacity fading and excess use of electrolyte, which severely bottlenecks practical use of $\mathrm{Li}$-S batteries. Here selective catalysis is proposed as a fundamental remedy for the consecutive solid-liquid-solid sulfur redox reactions. The proof-of-concept $\mathrm{In}_{2} \mathrm{O}_{3}$ catalyst targetedly slows down the solid-liquid conversion, dissolution of elemental sulfur to polysulfides, while accelerates the liquid-solid conversion, deposition of polysulfides into insoluble $\mathrm{Li}_{2} \mathrm{~S}$, which basically reduces accumulation of polysulfides in electrolyte, finally inhibiting the shuttle effect. The selective catalysis is revealed, experimentally and theoretically, by changes of activation energies and kinetic currents, modified reaction pathway together with the probed $\mathrm{LinS}_{2}$ intermediates, and gradual deactivation of the catalyst. The $\mathrm{In}_{2} \mathrm{O}_{3}$-catalysed Li-S battery works steadily over 1000 cycles at $4.0 \mathrm{C}$ and yields an initial areal capacity up to $9.4 \mathrm{mAh} \mathrm{cm}^{-2}$ with a sulfur loading of $\sim 9.0 \mathrm{mg} \mathrm{cm}^{-2}$.

${ }^{1}$ Nanoyang Group, State Key Laboratory of Chemical Engineering, School of Chemical Engineering and Technology, Tianjin University, Tianjin 300350, China; ${ }^{2}$ Key Laboratory of Resource Chemistry of Ministry of Education, Shanghai Key Laboratory of Rare Earth Functional Materials, Department of Chemistry, Shanghai Normal University, Shanghai 200234, China; ${ }^{3}$ School of Chemical Engineering and Advanced Materials, The University of Adelaide, Adelaide, SA 5005, Australia; ${ }^{4}$ School of Marine Science and Technology, Tianjin University, Tianjin 300072, China; ${ }^{5}$ Shenzhen Key Laboratory for Graphene-based Materials and Engineering Laboratory for Functionalized Carbon Materials, Graduate School at Shenzhen, Tsinghua University, Shenzhen 518055, China; ${ }^{6}$ Shenyang National Laboratory for Materials Science, Institute of Metal Research, Chinese Academy of Sciences, Shenyang 110016, China. †These authors are equal main contributors. Corresponding E-mails: ywan@shnu.edu.cn; qhyangcn@tju.edu.cn. 


\section{Introduction}

Lithium-sulfur (Li-S) batteries show great promise among future battery techniques due to their theoretically high energy density $\left(\sim 2600 \mathrm{Wh} \mathrm{kg}^{-1}\right)$, low cost and environmental benign. ${ }^{1-2}$ However, their real use in large scale is still plagued with challenges, such as the poor electrical conductivity of sulfur and solid-state discharge products $\left(\mathrm{Li}_{2} \mathrm{~S}_{2} \mathrm{Li}_{2} \mathrm{~S}_{2}\right)$, and the large volume change ( $\left.80 \%\right)$ of the sulfur cathode during cycling. ${ }^{3-4}$ The operation of Li-S batteries involves solid-liquid-solid consecutive reactions both for the discharge and charge process and creates a series of polysulfide ions ( $\mathrm{LiPSs}$, also denoted $\mathrm{Li}_{2} \mathrm{~S}_{\mathrm{n}}, 4 \leqslant \mathrm{n} \leqslant 8$ ) that are soluble and mobile in the organic electrolytes. Thus, a more serious problem for the practical Li-S batteries is the shuttling of the soluble $\mathrm{Li}_{2} \mathrm{~S}_{\mathrm{n}}$ from the cathode to anode side to form non-reusable solid $\mathrm{Li}_{2} \mathrm{~S}_{2} / \mathrm{Li}_{2} \mathrm{~S}$, which causes the so-called "shuttle effect". This bottlenecks the real applications with rapid capacity fade (short cycling life) and excess use of electrolyte (far lower energy density than the theoretical value). ${ }^{3,5}$-6 Physical confinement (Schemes 1a) mostly with porous carbons and chemical anchoring (Schemes 1b) by polar substrates are commonly used to inhibit the shuttle effect. ${ }^{7-13}$ However, both strategies intrinsically are passive solutions, where $\mathrm{Li}_{2} \mathrm{~S}_{\mathrm{n}}$ are "confined" and "blocked" in the cathode system. The shuttle effect is basically driven by the concentration gradient of the soluble $\mathrm{Li}_{2} \mathrm{~S}_{\mathrm{n}},{ }^{3}$ and thus a root solution is required that accelerates the conversion of $\mathrm{Li}_{2} \mathrm{~S}_{\mathrm{n}}$ in the sulfur reduction reaction (SRR, corresponding to discharge process) and sulfur evolution reaction (SER, corresponding to charge process) to reduce the opportunities of the $\mathrm{Li}_{2} \mathrm{~S}_{\mathrm{n}}$ shuttling and finally suppressing the shuttle effect.

Catalysis has recently been introduced into Li-S batteries as such a proactive strategy for accelerating the conversion of $\mathrm{Li}_{2} \mathrm{~S}_{\mathrm{n}}$ and thereby tackling the shuttle effect, ${ }^{14,15}$ and sulfides, nitrides, phosphides and their heterostructures were employed as the catalysts. ${ }^{16-25}$ Most recently, Peng et al. have presented a fundamental look at the catalysis in Li-S batteries. ${ }^{26}$ Specially, they directly profile the electron-transfer numbers to characterize the electrocatalytic sulfur reduction and confirm catalysis as a promising pathway to tackle the fundamental challenges for Li-S batteries. However, what is the "right" catalyst for Li-S batteries towards a practical application remains unclear. The root cause of the shuttle effect is the accumulation of soluble $\mathrm{Li}_{2} \mathrm{~S}_{\mathrm{n}}$ in the consecutive solid-liquid-solid reactions, and therefore, as shown in Scheme 1c, we propose that an ideal catalyst for the discharge process is expected not only to accelerates the liquid-solid reaction, deposition of $\mathrm{Li}_{2} \mathrm{~S}_{\mathrm{n}}$ into insoluble $\mathrm{Li}_{2} \mathrm{~S}$, as reported widely, ${ }^{15}$ but also to slow down the previous step of solid-liquid reaction, dissolution of elemental sulfur to $\mathrm{Li}_{2} \mathrm{~S}_{\mathrm{n}}$; the composition of "accelerating" and "slowing-down" basically reduces the accumulation of polysulfides in the 

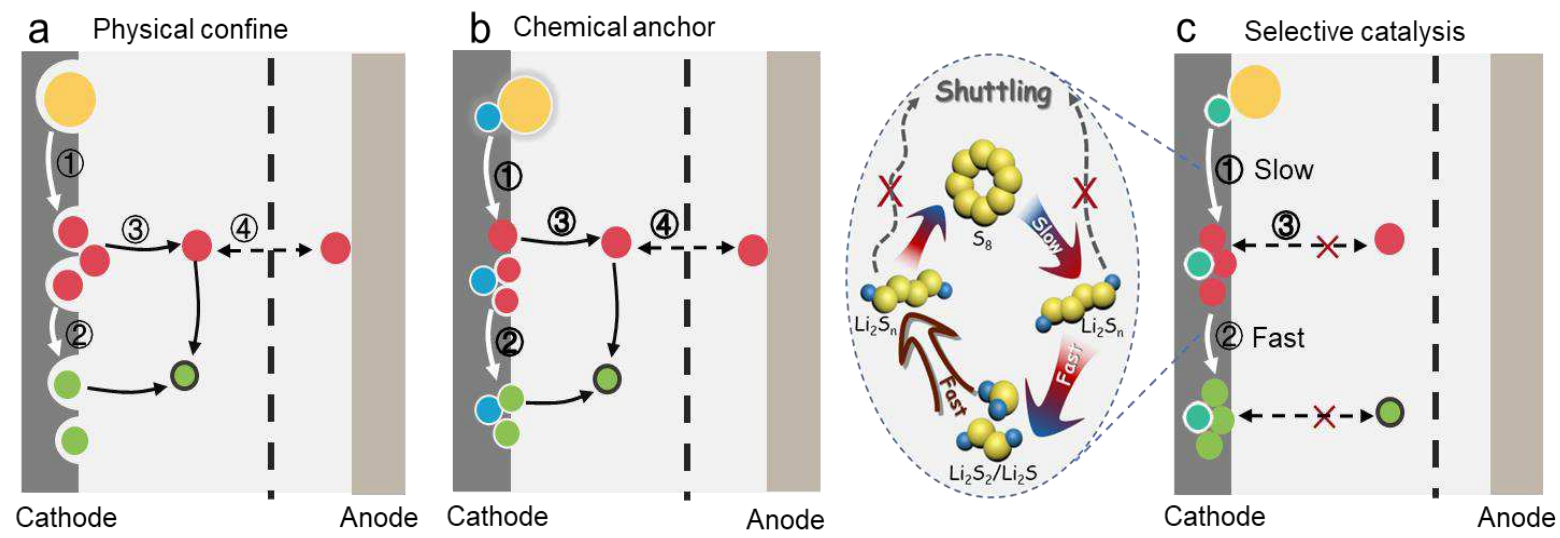

(1) Dissolution (2) Precipitation (3) Diffusion (4) Shuttling

Sulfur $\mathrm{LiPSs} \mathrm{Li}_{2} \mathrm{~S}$ Olrreversible sulfur Anchoring materials $\ln _{2} \mathrm{O}_{3}$ catalyst

Scheme 1 Strategies to tackcle "shuttle effect" of soluble lithium polysulfides $\left(\operatorname{Li}_{2} S_{n}\right)$ : physical confinement (a), chemical anchoring (b) and selective catalysis (c). Physical confinement and chemical anchoring are the most common ways to trap the soluble $\mathrm{Li}_{2} \mathrm{~S}_{\mathrm{n}}$, working as follows: 1) the elemental sulfur gets electrons and forms $\mathrm{Li}_{2} \mathrm{~S}_{\mathrm{n}}$ on the conductive substrate; 2) the trapped $\mathrm{Li}_{2} \mathrm{~S}_{\mathrm{n}}$ are further reduced to $\mathrm{Li}_{2} \mathrm{~S}$ on the conductive substrate; 3) other $\mathrm{Li}_{2} \mathrm{~S}_{\mathrm{n}}$ are released from the conductive substrate and dissolved in the electrolyte; 4) Some of the dissolved $\mathrm{Li}_{2} \mathrm{~S}_{\mathrm{n}}$ shuttle to the lithium metal side and then transfer back to the cathode side, resulting in the shuttle effect; the shuttled $\mathrm{Li}_{2} \mathrm{~S}_{\mathrm{n}}$ result in a continuous loss of active sulfur and the corrosion of Li anodes. Selective catalysis is proposed in this study as a fundamental remedy for reducing the accummulation of soluble $\mathrm{Li}_{2} \mathrm{~S}_{\mathrm{n}}$ and finally inhibiting the shuttle effect. For the discharging, the catalysis selectively slows down dissolution of elemental sulfur to $\mathrm{Li}_{2} \mathrm{~S}_{\mathrm{n}}$ while accelerates the deposition of $\mathrm{Li}_{2} \mathrm{~S}_{\mathrm{n}}$ into insoluble $\mathrm{Li}_{2} \mathrm{~S}$.

In this work, we use nanoparticulated indium oxides $\left(\mathrm{In}_{2} \mathrm{O}_{3} \mathrm{NP}\right)$ as a proof-of-concept catalyst to demonstrate the selective catalysis for the consecutive solid-liquid-solid reaction, which is not only confirmed by the changes of kinetic currents and activation energies of different steps of sulfur redox reaction, but also in-situ monitoring of the modified reaction pathway together with the probed catalytic intermediate, $\operatorname{LinS}_{2}$, as well as the featured catalyst deactivation. The SRR process (discharge) of the assembled battery well characterizes the selective catalysis, where the $\operatorname{In}_{2} \mathrm{O}_{3}$ catalyst, with strong adsorption towards elemental sulfur, slows down the dissolution of elemental sulfur to soluble $\mathrm{Li}_{2} \mathrm{~S}_{\mathrm{n}}$, while accelerates the $\mathrm{Li}_{2} \mathrm{~S}_{\mathrm{n}}$ disposition to insoluble $\mathrm{Li}_{2} \mathrm{~S}$ due to the strong catalytic ability with $\mathrm{LiInS} \mathrm{S}_{2}$ intermediates. For the SER process (charge), the catalysis with the probed $\mathrm{LinS}_{2}$ intermediates greatly reduces the energy barrier of $\mathrm{Li}_{2} \mathrm{~S}$ being oxidized to $\mathrm{Li}_{2} \mathrm{~S}_{\mathrm{n}}$ and eventually converted to elemental sulfur, which, however, is hardly accomplished in the catalyst-free cell under the same charge voltage. Benefiting from the catalysis, the Li-S battery cell shows a good cycling stability and works steadily with negligible capacity decay over 1000 cycles at an ultrahigh 
rate of $4.0 \mathrm{C}$; moreover, the battery displays a high initial areal capacity up to $9.4 \mathrm{mAh} \mathrm{cm}^{-2}$ at a current density of $0.9 \mathrm{~mA} \mathrm{~cm}{ }^{-2}$ even with a high sulfur loading $\left(\sim 9.0 \mathrm{mg} \mathrm{cm}^{-2}\right)$. This work featured with selective catalysis rightly indicates a rational design principle for the catalysts towards a practical Li-S battery with suppressed shuttle effect.

\section{Results}
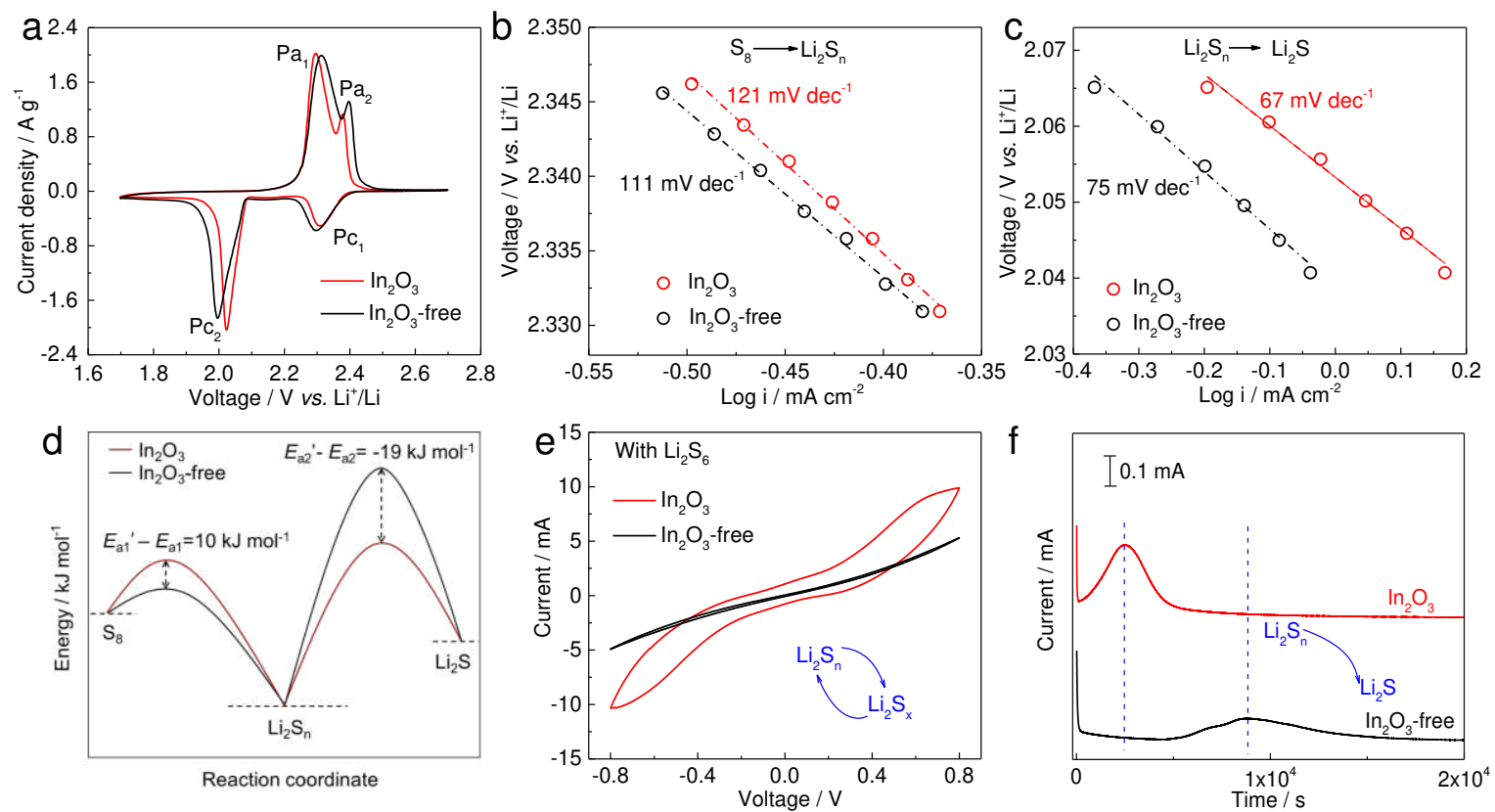

Figure 1. Electrochemical properties of $\mathrm{In}_{2} \mathrm{O}_{3}$-catalyzed cathode in comparison to the $\mathrm{In}_{2} \mathrm{O}_{3}$-free case. (a) the second cycle of CV profiles for the $\mathrm{In}_{2} \mathrm{O}_{3}$-catalyzed and $\mathrm{In}_{2} \mathrm{O}_{3}$-free Li-S cells at a low scan rate of $0.1 \mathrm{mV} \mathrm{s}^{-1}$ and $(\mathrm{b}, \mathrm{c})$ Tafel plots corresponding to the reductions of elemental sulfur to $\mathrm{Li}_{2} \mathrm{~S}_{\mathrm{n}}$ and $\mathrm{Li}_{2} \mathrm{~S}_{\mathrm{n}}$ to $\mathrm{Li}_{2} \mathrm{~S}$; (d) the relative activation energies of the two sulfur cathodes, where the $\mathrm{In}_{2} \mathrm{O}_{3}-$ catalyzed cathode shows a higher energy barrier for the conversion from $\mathrm{S}_{8}$ to $\mathrm{Li}_{2} \mathrm{~S}_{\mathrm{n}}$, but a lower energy barrier for the $\mathrm{Li}_{2} \mathrm{~S}_{\mathrm{n}}-\mathrm{to}-\mathrm{Li}_{2} \mathrm{~S}$ conversion, in comparison to the $\mathrm{In}_{2} \mathrm{O}_{3}$-free case; (e) CV curves of symmetric dummy cells using $\operatorname{In}_{2} \mathrm{O}_{3}$-catalyzed and $\mathrm{In}_{2} \mathrm{O}_{3}$-free electrodes at a rapid scan rate of $20 \mathrm{mV} \mathrm{s}^{-1}$; (f) potentiostatic discharge curves of a $\mathrm{Li}_{2} \mathrm{~S}_{8} /$ tetraglyme solution at $2.05 \mathrm{~V}$ on the $\mathrm{In}_{2} \mathrm{O}_{3}$ catalyzed and $\operatorname{In}_{2} \mathrm{O}_{3}$-free electrodes.

Selective catalysis in the consecutive redox reaction. To evaluate the $\operatorname{In}_{2} \mathrm{O}_{3}$ catalyst for the Li-S batteries, $\operatorname{the}_{2} \operatorname{In}_{2} \mathrm{O}_{3}$ NPs were hybridized with a porous carbon support composed of reduced graphene oxides $(\mathrm{G})$ and carbon nanotubes (CNT), which yielded a $\operatorname{In}_{2} \mathrm{O}_{3}$-based cathode denoted $\operatorname{In}_{2} \mathrm{O}_{3}$-G-CNT/S (an optimized $2.8 \mathrm{wt} \% \operatorname{In}_{2} \mathrm{O}_{3}$ ) accommodating $\sim 70 \mathrm{wt} \%$ sulfur (see the preparation details in Supplementary Fig. 1-3 and Supplementary Note 1). For reference, the catalyst-free sample (G-CNT/S) was prepared with the same procedure except for the absence of $\operatorname{In}_{2} \mathrm{O}_{3}$. Cyclic voltammetry (CV) curves for the $\operatorname{In}_{2} \mathrm{O}_{3}$-catalyzed and $\mathrm{In}_{2} \mathrm{O}_{3}$-free cells were compared in Figure 1a that were respectively assembled by coupling $\operatorname{In}_{2} \mathrm{O}_{3}$-contained and $\operatorname{In}_{2} \mathrm{O}_{3}$-free cathodes with the referenced $\mathrm{Li}$ foil anodes. For 
the discharge, the two cathodic (reduction) peaks $\left(\mathrm{Pc}_{1}, \mathrm{Pc}_{2}\right)$ correspond to the reduction of elemental sulfur $\left(\mathrm{S}_{8}\right)$ to $\mathrm{Li}_{2} \mathrm{~S}_{\mathrm{n}}$ and then to $\mathrm{Li}_{2} \mathrm{~S}$, respectively. For the charge, two distinguishable anodic (oxidation) peaks $\left(\mathrm{Pa}_{1}, \mathrm{~Pa}_{2}\right)$ are observed, which are respectively attributed to the conversions from $\mathrm{Li}_{2} \mathrm{~S}$ to $\mathrm{Li}_{2} \mathrm{~S}_{\mathrm{n}}$, and finally to elemental sulfur $\left(\mathrm{S}_{8}\right) \cdot{ }^{27}$ When compared to that of $\mathrm{In}_{2} \mathrm{O}_{3}$-free case, the CV curve of the $\mathrm{In}_{2} \mathrm{O}_{3}$-catalyzed cell shows a definite positive shift of the cathodic peak and negative shift of the anodic peak (Supplementary Fig. 9 and Supplementary Table 1), indicating the catalytic activity of $\operatorname{In}_{2} \mathrm{O}_{3} .{ }^{14,15}$ Specially, the $\operatorname{In}_{2} \mathrm{O}_{3}$-catalyzed cell shows a slightly lower kinetic current than the $\mathrm{In}_{2} \mathrm{O}_{3}$-free cell for the dissolution from $\mathrm{S}_{8}$ to $\mathrm{Li}_{2} \mathrm{~S}_{\mathrm{n}}$ as observed by the $\mathrm{Pc}_{1}$ peak in Figure 1a. By comparison, the $\mathrm{Li}_{2} \mathrm{~S}_{\mathrm{n}}$-to- $\mathrm{Li}_{2} \mathrm{~S}$ conversion is greatly enhanced due to the presence of catalyst, which is evidenced by the apparently larger current density of $\mathrm{Pc}_{2}$. The different changes (reduced or enhanced) of the kinetic currents for various reaction steps concisely prove the selective catalysis during the discharge process.

The selective catalysis is further confirmed by the comparation of Tafel plots for $\operatorname{In}_{2} \mathrm{O}_{3}$-catalyzed and $\operatorname{In}_{2} \mathrm{O}_{3}$-free cells (Figures $1 \mathrm{~b}, \mathrm{c}$ ). The reduction and oxidation overpotentials of $\mathrm{Li}_{2} \mathrm{~S}_{\mathrm{n}}$ have been significantly decreased due to the introduction of the $\mathrm{In}_{2} \mathrm{O}_{3}$ catalyst (Figure 1c and Supplementary Fig. 10). Exchange current densities were calculated from the Tafel plots, which reflect the intrinsic electron transfer rate between electrode and electrolyte (Supplementary Table 1). The $\operatorname{In}_{2} \mathrm{O}_{3}$-catalyzed cell shows larger exchange current densities in both discharge and charge process, which are 6.02 and $0.20 \mathrm{~mA} \mathrm{~cm}^{-2}$ respectively, compared to those of $\operatorname{In}_{2} \mathrm{O}_{3}$-free case $(3.29$ and 0.16 $\mathrm{mA} \mathrm{cm}{ }^{-2}$ ). The increase of exchange current densities indicates faster charge transfer induced by the $\operatorname{In}_{2} \mathrm{O}_{3}$ catalyst. The Tafel slope, which is an indicator for the kinetics of sulfur redox reactions, was further compared between $\operatorname{In}_{2} \mathrm{O}_{3-}$ catalyzed and $\mathrm{In}_{2} \mathrm{O}_{3}$-free cells. Very interestingly, the $\mathrm{In}_{2} \mathrm{O}_{3}$-catalyzed cell shows the higher Tafel slope of $121 \mathrm{mV}$ $\mathrm{dec}^{-1}$ for the $\mathrm{S}_{8}$-to- $\mathrm{Li}_{2} \mathrm{~S}_{\mathrm{n}}$ conversion than the $\mathrm{In}_{2} \mathrm{O}_{3}$-free case $\left(111 \mathrm{mV} \mathrm{dec}{ }^{-1}\right)$, while the lower Tafel slope of $67 \mathrm{mV}$ $\mathrm{dec}^{-1}$ for the $\mathrm{Li}_{2} \mathrm{~S}_{\mathrm{n}}$-to- $\mathrm{Li}_{2} \mathrm{~S}$ conversion compared with the $\mathrm{In}_{2} \mathrm{O}_{3}$-free case $\left(75 \mathrm{mV} \mathrm{dec}{ }^{-1}\right)$, indicating the decreased solid-to-liquid conversion rate while accelerated liquid-to-solid conversion. The difference in activation energy $\left(E_{\mathrm{a}}\right)$ can be calculated from the exchange current densities (see details in Supplementary Note 2). As shown in Figure 1d, the $E_{a}$ value for the reduction for $\mathrm{S}_{8}$ to $\mathrm{Li}_{2} \mathrm{~S}_{\mathrm{n}}$ is increased by $10 \mathrm{~kJ} \mathrm{~mol}^{-1}$ for the $\mathrm{In}_{2} \mathrm{O}_{3}$-catalyzed cell as compared to that for the $\mathrm{In}_{2} \mathrm{O}_{3}$-free case, also indicating that the formation rate of $\mathrm{Li}_{2} \mathrm{~S}_{\mathrm{n}}$ slows down. In the following reaction step, the $E_{\mathrm{a}}$ value for the reduction of $\mathrm{Li}_{2} \mathrm{~S}_{\mathrm{n}}$ to $\mathrm{Li}_{2} \mathrm{~S}$ is greatly decreased by $19 \mathrm{~kJ} \mathrm{~mol}^{-1}$ with the $\mathrm{In}_{2} \mathrm{O}_{3}$-catalyzed cell as compared to the $\mathrm{In}_{2} \mathrm{O}_{3}$-free case, increasing their conversion rate. The increase of the activation energy for the formation of $\mathrm{Li}_{2} \mathrm{~S}_{\mathrm{n}}$ and the obvious decrease in the activation energy for the following reduction to $\mathrm{Li}_{2} \mathrm{~S}$ strongly support the proposed selective catalysis, where the dissolution of $\mathrm{S}_{8}$ to $\mathrm{Li}_{2} \mathrm{~S}_{\mathrm{n}}$ becomes more sluggish but the 
conversion from $\mathrm{Li}_{2} \mathrm{~S}_{\mathrm{n}}$ to $\mathrm{Li}_{2} \mathrm{~S}$ goes faster by using the $\mathrm{In}_{2} \mathrm{O}_{3}$ catalyst. For the charge, the $E_{\mathrm{a}}$ value for the oxidation of $\mathrm{Li}_{2} \mathrm{~S}$ to $\mathrm{Li}_{2} \mathrm{~S}_{\mathrm{n}}$ is greatly decreased by $74 \mathrm{~kJ} \mathrm{~mol}^{-1}$ with $\mathrm{In}_{2} \mathrm{O}_{3}$ catalyst compared to that of the $\operatorname{In}_{2} \mathrm{O}_{3}$-free case, indicating accelerated conversion of the deposited $\mathrm{Li}_{2} \mathrm{~S}$ and a cleaned-up surface (Supplementary Note 2 and Supplementary Fig. 11). Besides, the $\operatorname{In}_{2} \mathrm{O}_{3}$-catalyzed cell shows the lower charge-transfer resistance $\left(\mathrm{R}_{\mathrm{ct}}\right)$ as identified by the electrochemical impedance spectroscopy (EIS) data (Supplementary Fig. 12), suggesting an enhanced interfacial affinity towards $\mathrm{Li}_{2} \mathrm{~S}_{\mathrm{n}}$ with the $\mathrm{In}_{2} \mathrm{O}_{3}$ catalyst. ${ }^{28}$

$\mathrm{CV}$ tests were further carried out for the symmetric dummy cells that were assembled by coupling two same $\operatorname{In}_{2} \mathrm{O}_{3-}$ catalyzed electrodes with $\mathrm{Li}_{2} \mathrm{~S}_{6}$ electrolyte (Figure 1e). As expected, the $\mathrm{In}_{2} \mathrm{O}_{3}$-catalyzed cell shows a much higher current density than the $\mathrm{In}_{2} \mathrm{O}_{3}$-free case even at a fast scan rate of $20 \mathrm{mV} \mathrm{s}^{-1}$, indicating the ultrafast conversion of $\mathrm{Li}_{2} \mathrm{~S}_{\mathrm{n}} \cdot{ }^{28,29}$ Potentiostatically $\mathrm{Li}_{2} \mathrm{~S}$ precipitation test is specially used for evaluating the $\mathrm{Li}_{2} \mathrm{~S}_{\mathrm{n}}$-to- $\mathrm{Li}_{2} \mathrm{~S}$ conversion with the $\mathrm{In}_{2} \mathrm{O}_{3}$ catalyst. The coin cells for the tests were assembled using $\operatorname{In}_{2} \mathrm{O}_{3}$-loaded $\operatorname{or}_{2} \operatorname{In}_{2} \mathrm{O}_{3}$-free carbon fiber paper (CP) as the cathodes, $\mathrm{Li}$ foil as the anode, and a $\mathrm{Li}_{2} \mathrm{~S}_{8} /$ tetraglyme solution as the catholyte. As shown in Figure 1f, potentiostatic discharge profiles at $2.05 \mathrm{~V}$ were collected. The results show that the $\operatorname{In}_{2} \mathrm{O}_{3}$-catalyzed cell accelerates the $\mathrm{Li}_{2} \mathrm{~S}$ nucleation ( 2500 s) compared with that free of $\operatorname{In}_{2} \mathrm{O}_{3}$. In addition, the $\mathrm{Li}_{2} \mathrm{~S}$ precipitate for $\ln _{2} \mathrm{O}_{3-}$ catalyzed cell, which was evaluated based on the quantity of electric charge according to Faraday's law, shows a much higher capacity with a shorter nucleation time than those for the $\operatorname{In}_{2} \mathrm{O}_{3}$-free cell (Supplementary Fig. 13). Thus, $\mathrm{Li}_{2} \mathrm{~S}$ precipitation test gives a direct proof for the enhanced $\mathrm{Li}_{2} \mathrm{~S}_{\mathrm{n}}-\mathrm{to}-\mathrm{Li}_{2} \mathrm{~S}$ conversion with the $\mathrm{In}_{2} \mathrm{O}_{3}$ catalyst. ${ }^{28-31}$

Battery performance. $\mathrm{An} \mathrm{In}_{2} \mathrm{O}_{3}$-catalyzed battery was evaluated for rate and cycling performances in comparison to the $\mathrm{In}_{2} \mathrm{O}_{3}$-free battery also with an optimized $2.8 \mathrm{wt} \% \operatorname{In}_{2} \mathrm{O}_{3}$ in the cathode, where the battery gave the highest capacity at various rates (Supplementary Fig. 3a). The rate performances of the Li-S batteries assembled by coupling $\mathrm{In}_{2} \mathrm{O}_{3}$-catalyzed or $\mathrm{In}_{2} \mathrm{O}_{3}$-free cathodes with a $\mathrm{Li}$ foil anode are shown in Figure $2 \mathrm{a}$. With the catalyst, the battery achieves a high discharge capacity of $1427,876,773,692$ and $502 \mathrm{mAh} \mathrm{g}^{-1}$ at a rate of 0.2, 0.5, 1.0, 2.0 and $4.0 \mathrm{C}$, respectively, all of which are much higher than those for the $\mathrm{In}_{2} \mathrm{O}_{3}$-free batteries. When abruptly switching the rate from $4.0 \mathrm{C}$ back to the initial rate of $0.2 \mathrm{C}$, the original capacity is largely recovered, indicating the excellent reversible capacity of the $\mathrm{In}_{2} \mathrm{O}_{3}$-catalyzed battery at various rates. ${ }^{32,}{ }^{33} \mathrm{The} \mathrm{In}_{2} \mathrm{O}_{3}$-catalyzed battery shows a lower voltage difference $(\Delta E=131 \mathrm{mV})$ which was calculated based on the charge plateau and discharge plateau in the third cycle, as compared to the $\Delta E$ value of $141 \mathrm{mV}$ for the $\mathrm{In}_{2} \mathrm{O}_{3}$-free case. ${ }^{27}$ Besides, the $\operatorname{In}_{2} \mathrm{O}_{3}$-catalyzed battery exhibits much lower potential barrier in the charging process, indicating the activation energy $\left(E_{\mathrm{a}}\right)$ of the $\mathrm{Li}_{2} \mathrm{~S}-\mathrm{to}-\mathrm{Li}_{2} \mathrm{~S}_{\mathrm{n}}$ conversion is greatly reduced (Supplementary Fig.14), consistent with that obtained from Tafel plots. The charge-discharge 

curves of the batteries at various current rates (0.2-4.0 C) are illustrated in Figure 2c and Supplementary Fig.15. Note

2 that the typical two discharge plateaus of the $\operatorname{In}_{2} \mathrm{O}_{3}$-catalyzed battery are clearly seen even at a very high rate of 4.0

$3 \mathrm{C}$, while the second plateau of the $\mathrm{In}_{2} \mathrm{O}_{3}$-free battery, corresponding to the conversion of $\mathrm{Li}_{2} \mathrm{~S}_{\mathrm{n}}$ to $\mathrm{Li}_{2} \mathrm{~S}_{2} / \mathrm{Li}_{2} \mathrm{~S}$, disappears when cycled at this current.
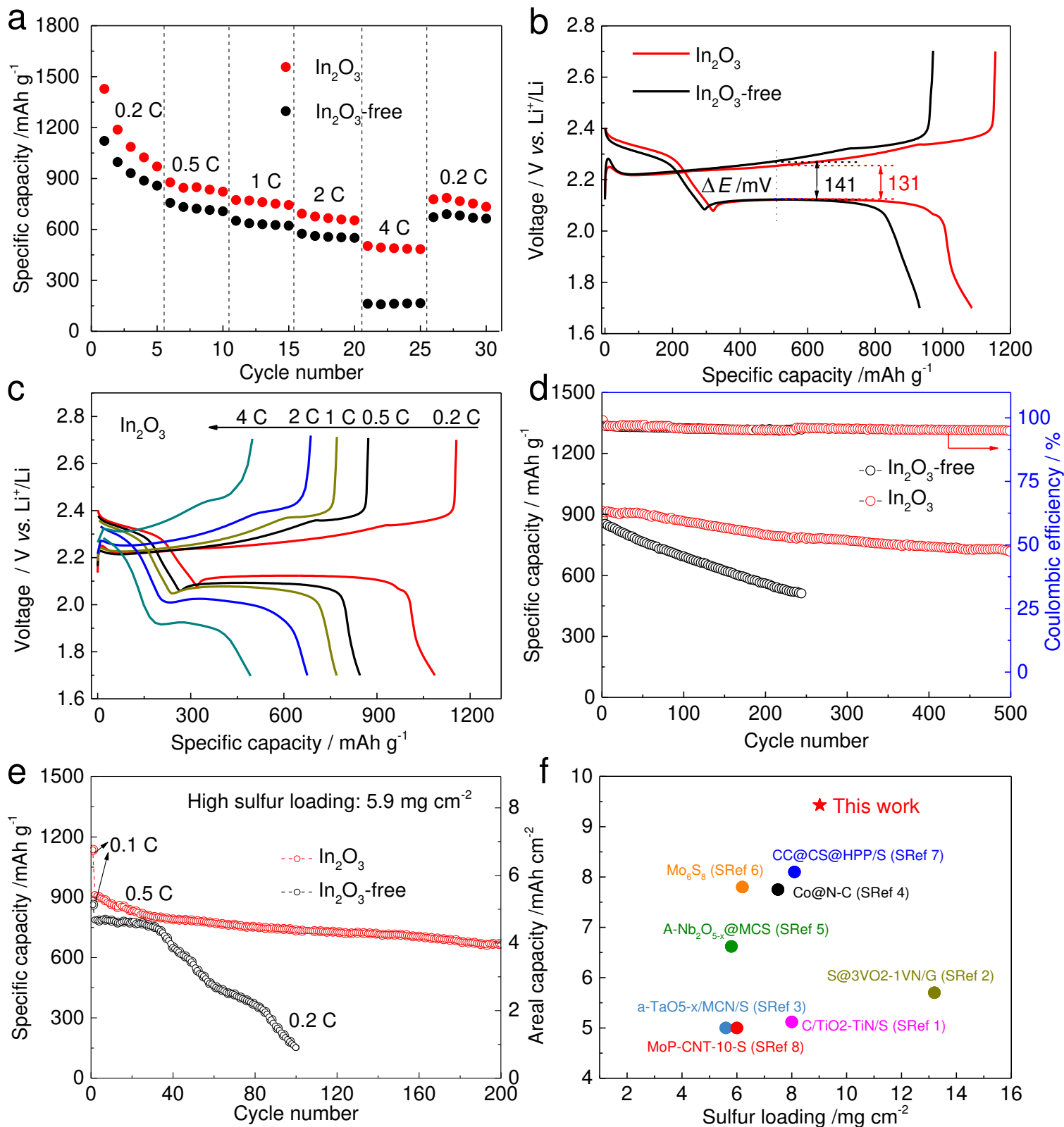

Figure 2. Electrochemical performance of $\mathrm{In}_{2} \mathrm{O}_{3}$-catalyzed $\mathrm{Li}-\mathrm{S}$ battery in comparison to the $\mathrm{In}_{2} \mathrm{O}_{3}$-free battery. (a) rate performance $\left(1 \mathrm{C}=1675 \mathrm{~mA} \mathrm{~g}^{-1}\right)$; (b) galvanostatic discharge-charge profiles at $0.2 \mathrm{C}$; (c) galvanostatic charge-discharge profiles of the $\mathrm{In}_{2} \mathrm{O}_{3}$-catalyzed battery at various current rates; (d) cycling stability at $0.5 \mathrm{C}$; (e) cycling performance with a high sulfur mass loading of $5.9 \mathrm{mg} \mathrm{cm}^{-2}$ at $0.5 \mathrm{C}$ and $0.2 \mathrm{C}$; (f) a comparison with other sulfur cathodes with electrolyte/sulfur ratios $\leq 8 \mu \mathrm{L} / \mathrm{mg}$ (SRef: Supplementary References). 
The cycling performances were further compared at a $0.5 \mathrm{C}$ as shown in Figure $2 \mathrm{~d}$. $\mathrm{The}_{\mathrm{In}} \mathrm{O}_{3}$-catalyzed battery exhibits superior capacity retention with stable coulombic efficiency. Specifically, it maintains a high capacity of 721 $\mathrm{mAh}^{-1}$ after 500 cycles with a small capacity degradation of $0.04 \%$ per cycle. In a sharp contrast, for the $\mathrm{In}_{2} \mathrm{O}_{3^{-}}$ free battery, the capacity quickly decays to $511 \mathrm{mAh} \mathrm{g}^{-1}$ with $0.17 \%$ decay per cycle over 250 cycles. The excellent cycling performance of the $\operatorname{In}_{2} \mathrm{O}_{3}$-catalyzed cell indicates the great suppression of the shuttling effect. ${ }^{18,34}$ The SEM images (Supplementary Fig. 16 a-d) show that for the $\operatorname{In}_{2} \mathrm{O}_{3}$-catalyzed cell, the discharge products are homogeneously distributed at the surface after cycling at $0.5 \mathrm{C}$, while, for the $\mathrm{In}_{2} \mathrm{O}_{3}$-free case, the cracked and exposed filaments are seen.

The cathodes with high sulfur loadings were fabricated to evaluate the potential for practical applications. ${ }^{35}$ The $\mathrm{In}_{2} \mathrm{O}_{3}$-catalyzed battery with a high sulfur areal loading up to $5.9 \mathrm{mg} \mathrm{cm}^{-2}$ delivers a higher initial capacity of 906 $\mathrm{mAh} \mathrm{g}^{-1}$, and a reversible capacity is maintained at $665 \mathrm{mAh} \mathrm{g}^{-1}$ with the retention of $73.4 \%$ over 200 cycles at 0.5 $\mathrm{C}$; the initial capacity and its retention capability are much superior to those of the $\operatorname{In}_{2} \mathrm{O}_{3}$-free battery even at a current density of $0.2 \mathrm{C}$ (Figure 2e). When the areal sulfur loading increases to $9.0 \mathrm{mg} \mathrm{cm}^{-2}$, the $\mathrm{In}_{2} \mathrm{O}_{3}$-catalyzed battery displays a high initial areal capacity up to $9.4 \mathrm{mAh} \mathrm{cm}^{-2}\left(1046 \mathrm{mAh} \mathrm{g}^{-1}\right)$ at a current density of $0.9 \mathrm{~mA} \mathrm{~cm}^{-2}$ even with a low electrolyte/sulfur ratio $\left(8 \mu \mathrm{L} \mathrm{mg}^{-1}\right)$; with an increased current density up to $1.8 \mathrm{~mA} \mathrm{~cm}^{-2}$, the battery can be steadily cycled over 100 cycles with a reversible areal capacity of $5.3 \mathrm{mAh} \mathrm{cm}{ }^{-2}$, much higher than that of the commercial Li-ion batteries $\left(\sim 4.0 \mathrm{mAh} \mathrm{cm}^{-2}\right)$ (Supplementary Fig. 17). ${ }^{33}$ The corresponding discharge plateaus are clearly seen even at such a high sulfur mass loading as shown in Supplementary Fig.18. In short, the areal capacities with high sulfur loadings are remarkable when compared to those for the reported sulfur hosts (Figure $2 \mathrm{f}$ and Supplementary Table 2). This excellent stability with high sulfur loadings strongly implies that the $\mathrm{In}_{2} \mathrm{O}_{3}$ nanocatalysts effectively prevent the accumulation of $\mathrm{Li}_{2} \mathrm{~S}_{\mathrm{n}}$ in the electrolyte and decrease the need of electrolyte to some extent. ${ }^{36}$

Reaction pathway in-situ monitored by Raman spectroscopy. The Raman spectroscopy with $532 \mathrm{~nm}$ laser was employed to monitor the charge-discharge process of Li-S batteries with or without $\operatorname{In}_{2} \mathrm{O}_{3}$ catalyst. As shown in Figures 3a, b, for the discharge, the peaks located at 156, 223 and $476 \mathrm{~cm}^{-1}$ for elemental sulfur ( $\left.\mathrm{S}_{8}\right)$ and 134 and 310 $\mathrm{cm}^{-1}$ for $\mathrm{In}_{2} \mathrm{O}_{3}$ are detected at the open-circuit voltage (OCV) for the $\mathrm{In}_{2} \mathrm{O}_{3}$-catalyzed cell. ${ }^{37,} 38$ Three characteristic peaks of $\mathrm{S}_{8}$ remain until $2.04 \mathrm{~V}$, indicative of strong adsorption of elemental sulfur on $\mathrm{In}_{2} \mathrm{O}_{3}$ and sluggish conversion to $\mathrm{Li}_{2} \mathrm{~S}_{\mathrm{n}}$. Upon the second plateau at $2.08 \mathrm{~V}$ a new peak at $398 \mathrm{~cm}^{-1}$ appears, attributed to the formation of $\mathrm{Li}_{2} \mathrm{~S}_{\mathrm{n}}$. When the voltage decreases to the end of the second plateau $(\sim 1.95 \mathrm{~V})$, new peaks located at 448,203 and $514 \mathrm{~cm}^{-1}$ 


$$
\text { - } \mathrm{S}_{8} \quad \Delta \operatorname{In}_{2} \mathrm{O}_{3} \quad \Delta \text { LilnS }_{2} \quad \odot \mathrm{Li}_{2} \mathrm{~S}_{\mathrm{n}} \quad \nRightarrow \mathrm{Li}_{2} \mathrm{~S}_{2}
$$

a $\begin{array}{llllllll}100 & 200 & 300 & 400 & 500 & 600 & 700 & \mathbf{C}\end{array}$

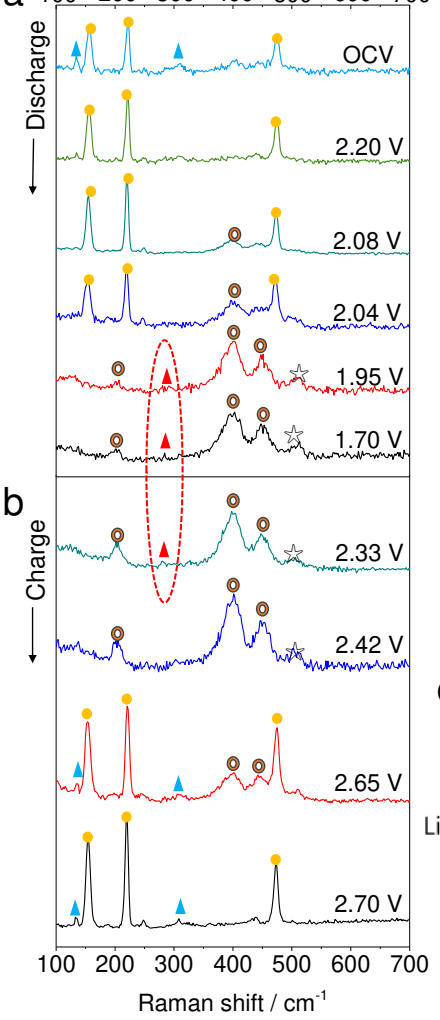

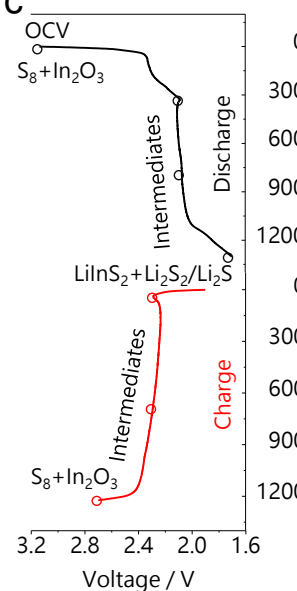

d

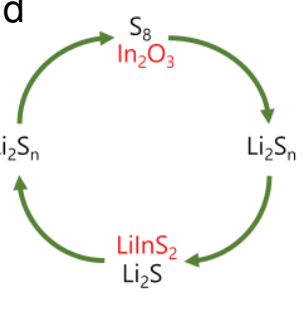

e $100 \quad 200 \quad 300 \quad 400 \quad 500 \quad 600 \quad 700 \mathrm{~g}$

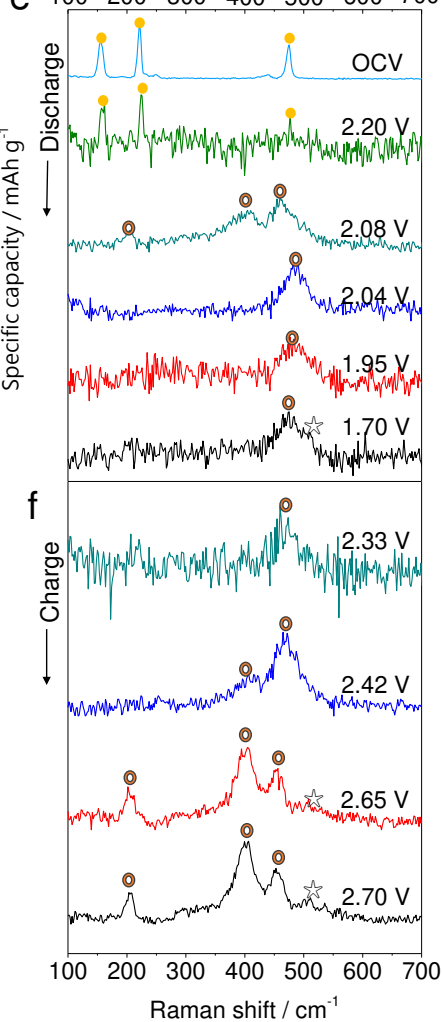

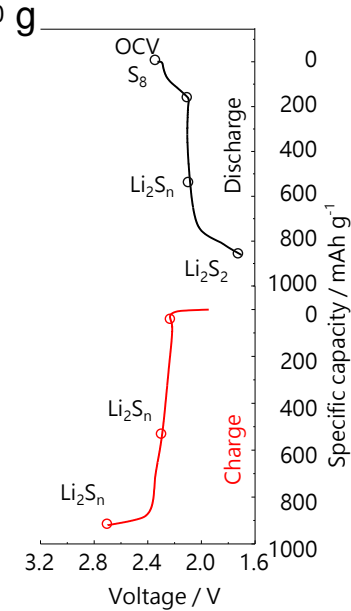

$\mathrm{h}$

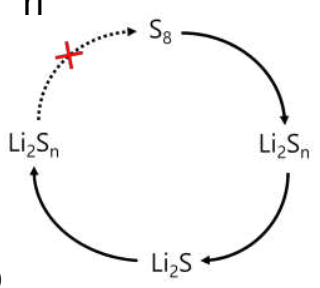

Figure 3. Reaction pathway demonstrated by in-situ Raman measurements. (a, b) Raman spectra of an $\mathrm{In}_{2} \mathrm{O}_{3}$-catalyzed battery and (c) the corresponding charge-discharge potentials of the detected substances; (d) a complete cycle of the sulfur redox with In $2 \mathrm{O}_{3}$ catalyst; (e, f) Raman spectra of an $\mathrm{In}_{2} \mathrm{O}_{3}$-free battery and (g) the corresponding charge-discharge profile; (h) an incomplete cycle of the sulfur redox free of $\mathrm{In}_{2} \mathrm{O}_{3}$ catalyst. See more details in Supplementary Fig. 20. detected even the Li-S cell was discharged to $1.7 \mathrm{~V}$, which may be attributed to the sluggishness of solid state diffusion of $\mathrm{Li}$ ions and the signal is hard to be captured in the in-situ measurement. ${ }^{41}$ Of interests, the peaks of $\operatorname{In}_{2} \mathrm{O}_{3}$ disappear before discharging to $1.95 \mathrm{~V}$ (Figure 3a and Supplementary Fig. 19), and a new peak at $284.7 \mathrm{~cm}^{-1}$ is then detected, which is due to a combination of stretching and torsion of S-In bonds and Li atom translational movements, probing the $\mathrm{LiInS}_{2}$ intermediates involved in the catalytic process. ${ }^{42}$ Comparatively, in the $\operatorname{In}_{2} \mathrm{O}_{3}$-free cell, Raman results (Figure 3e) indicate much faster conversion from $\mathrm{S}_{8}$ to soluble $\mathrm{Li}_{2} \mathrm{~S}_{\mathrm{n}}$ by demonstrating that the three characteristic peaks of elemental S were weakened at $2.20 \mathrm{~V}$ and totally disappeared at $2.08 \mathrm{~V}$. However, it is hard to identify the solid discharge products even at $1.95 \mathrm{~V}$ for the $\mathrm{In}_{2} \mathrm{O}_{3}$-free battery; instead, the peaks for $\mathrm{Li}_{2} \mathrm{~S}_{\mathrm{n}}$ are still maintained indicative of high concentrations of $\mathrm{Li}_{2} \mathrm{~S}_{\mathrm{n}}$ in the electrolyte and a sluggish reduction to $\mathrm{Li}_{2} \mathrm{~S}$. The sharp comparison for $\mathrm{In}_{2} \mathrm{O}_{3}$-catalyzed and $\mathrm{In}_{2} \mathrm{O}_{3}$-free cells well coincide with the above activation energy calculations obtained with 
discharge process slowing down the $\mathrm{S}_{8}-$ to- $\mathrm{Li}_{2} \mathrm{~S}_{\mathrm{n}}$ conversion with a higher energy barrier while accelerating the $\mathrm{Li}_{2} \mathrm{~S}_{\mathrm{n}^{-}}$ to- $\mathrm{Li}_{2} \mathrm{~S}$ conversion with a reduced energy barrier.

For the charge process (Figure 3b), the $\mathrm{In}_{2} \mathrm{O}_{3}$ catalyst with the probed $\mathrm{LiInS}_{2}$ intermediates facilitates the $\mathrm{Li}_{2} \mathrm{~S}_{\text {fast }}$ and full conversion to soluble $\mathrm{Li}_{2} \mathrm{~S}_{\mathrm{n}}$ and eventually back to $\mathrm{S}_{8}$ as the battery is charged to $2.70 \mathrm{~V}$, completing a reaction cycle for sulfur redox reaction (Figures $3 \mathrm{c}$, d); in a sharp contrast, this is hardly accomplished in $\operatorname{In}_{2} \mathrm{O}_{3}$-free cell under the same charge voltage and no S peaks are detected at $2.70 \mathrm{~V}$ (Figure $3 \mathrm{f}$ ). In the other words, without the catalyst, the battery cannot have a complete sulfur redox cycle upon charging to $2.70 \mathrm{~V}$ (Figures $3 \mathrm{~g}, \mathrm{~h}$ ). More informatively, for $\mathrm{In}_{2} \mathrm{O}_{3}$-catalyzed battery, the disappearance of the $\mathrm{LinSS}_{2}$ intermediates, together with the re-detection of $\operatorname{In}_{2} \mathrm{O}_{3}$ peaks upon charging to $2.42 \mathrm{~V}$, indicates that $\mathrm{In}_{2} \mathrm{O}_{3}$ catalyst is highly reversible in accompany with a fully cycled sulfur redox reaction, indicating $\mathrm{LiInS}_{2}$ plays a crucial role in the catalysis in both discharge and charge processes.

We further combined the computational simulation to gain a better understanding on the formation of catalytic intermediates and the interaction between $\mathrm{Li}_{2} \mathrm{~S}_{\mathrm{n}}$ and $\mathrm{In}_{2} \mathrm{O}_{3}$ in comparison to the clean graphene. To construct an accurate model of $\operatorname{In}_{2} \mathrm{O}_{3}$ catalyst, we have captured the annular dark-field scanning transmission electron microscopy (ADF-STEM) image as displayed in Figure 4a. It shows a lattice fringe with spacings of 1.79 and $2.92 \AA$,

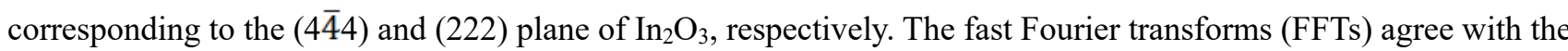
ADF-STEM images (Figure 4b), which were taken along the [-1-12] zone axis. Therefore, $\operatorname{In}_{2} \mathrm{O}_{3}(222)$ surface was selected to optimize the geometries of $\mathrm{Li}_{2} \mathrm{~S}_{\mathrm{n}}$ adsorption considering both of the ADF-STEM observations and XRD analysis (Supplementary Fig. 8). The result shows that $\mathrm{Li}_{2} \mathrm{~S}_{4}$ tends to form In-S bonds with In on the $\operatorname{In}_{2} \mathrm{O}_{3}(222)$ surface and the In-S bond lengths $(2.42,2.61 \AA)$ are close to that $(2.49 \AA)$ for the standard $\mathrm{LiInS}_{2}$ (Figure $\left.4 \mathrm{c}\right)$, which confirms the formation of the $\mathrm{LiInS}_{2}$ intermediates. Figure $4 \mathrm{~d}$ shows the $3 \mathrm{D}$ charge transfer maps between $\mathrm{Li}_{2} \mathrm{~S}_{4}$ and $\mathrm{In}_{2} \mathrm{O}_{3}$ with an isosurface value of $2 \times 10^{-3} \mathrm{e} \mathrm{bohr}^{-3}$. Obvious charge accumulation is observed at the interface between $\mathrm{S}$ and $\mathrm{In}_{2} \mathrm{O}_{3}$, which indicates the strong interaction between $\operatorname{In}_{2} \mathrm{O}_{3}$ and $\mathrm{Li}_{2} \mathrm{~S}_{\mathrm{n}}$. To give a clear view on the charge transfer state, we constructed a 2D charge maps of In, S and $\mathrm{O}$ atoms in Figure 4e, where the yellow and blue regions suggest the negative and positive charges, respectively. There are obviously accumulated positive charges around the In atom, indicating that $\mathrm{In}$ atom tends to dissolve from the $\mathrm{In}_{2} \mathrm{O}_{3}$ lattice. Figure $4 \mathrm{f}$ shows the projected density of the state (PDOS) of the surface In $3 d$ and S $2 p$. Obvious orbit overlapping of In $3 d$ and S $2 p$ is observed at the electron state around $-2 \mathrm{eV}$ below Fermi level, further confirming the interaction between In and $\mathrm{S}$ as well as the easy formation of $\mathrm{LinS}_{2}$ intermediates. Then, we investigated the binding energies between $\mathrm{S}_{8}$ and the substrates $\left(\operatorname{In}_{2} \mathrm{O}_{3}\right.$ 
a

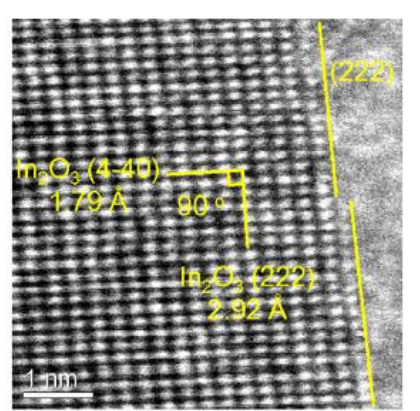

d

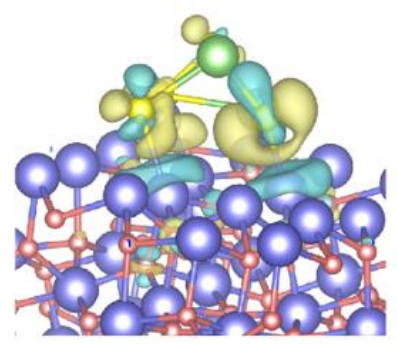

b

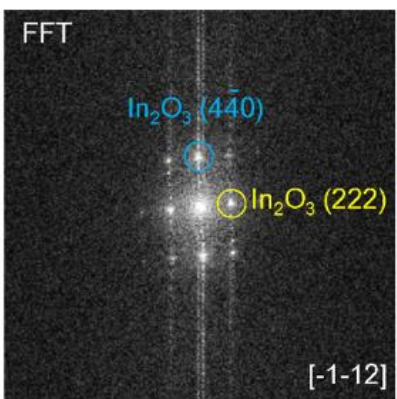

$e_{-1}$

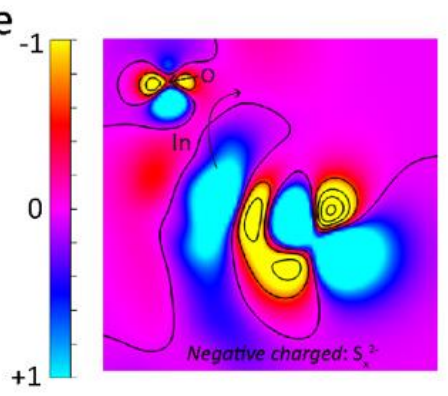

C
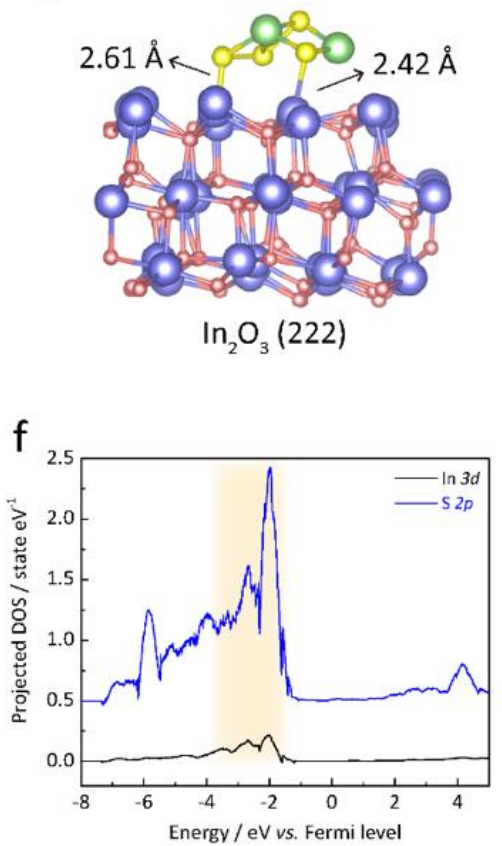

g
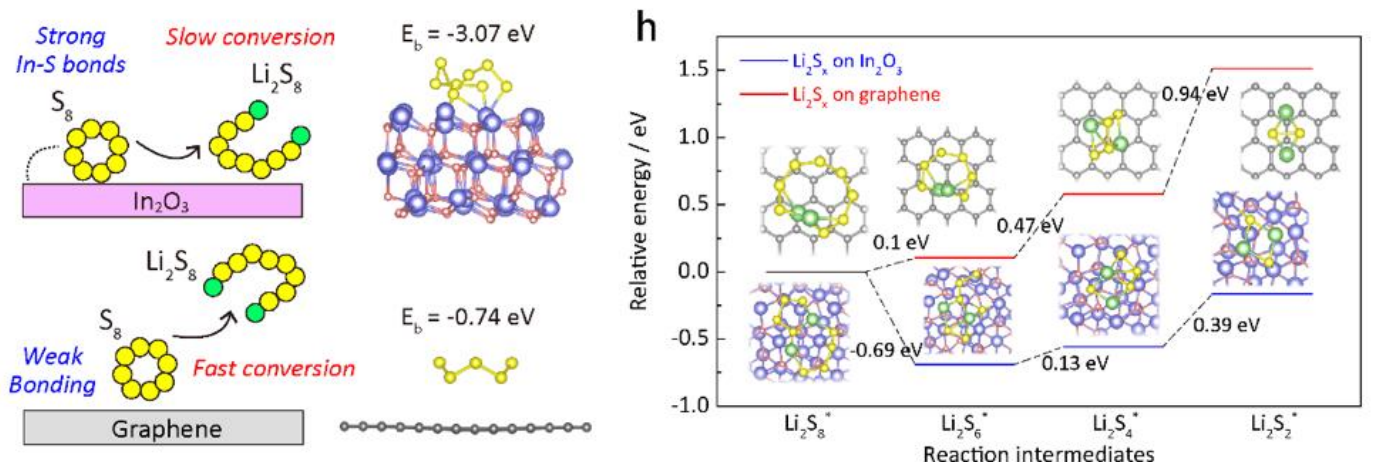

Figure 4. Computational simulation for the reaction pathway and $\mathrm{LiInS}_{2}$ intermediate. (a) ADF-STEM image of the G-In $\mathrm{O}_{3}$ hybrids; (b) the superimposed FFTs of $\operatorname{In}_{2} \mathrm{O}_{3}$; (c) the optimized structure of $\mathrm{Li}_{2} \mathrm{~S}_{4}$ on $\operatorname{In}_{2} \mathrm{O}_{3}$ surface; The In-S bond length are 2.42 and $2.61 \AA$, which are very close to the standard In-S bond length in $\mathrm{LiInS}_{2}(2.49 \AA)$; (d) 3D charge difference of $\mathrm{Li}_{2} \mathrm{~S}_{4}$ on $\mathrm{In}_{2} \mathrm{O}_{3}$; (e) $2 \mathrm{D}$ charge maps between In, $\mathrm{O}$ and $\mathrm{S}$; (f) the projected DOS of In $3 d$ and S $2 p$; (g) there is a much high binding energy of $-3.07 \mathrm{eV}$ between $\mathrm{In}_{2} \mathrm{O}_{3}$ and $\mathrm{S}_{8}$, compared to that of $-0.74 \mathrm{eV}$ of clean graphene substrate. Hence, $\mathrm{S} 8$ is hard to be desorbed from the $\mathrm{In}_{2} \mathrm{O}_{3} \mathrm{Surface}_{3}$, and this slows down the conversion from $\mathrm{S}_{8}$ to $\mathrm{Li}_{2} \mathrm{~S}_{8}$; (h) the reaction pathway from $\mathrm{Li}_{2} \mathrm{~S}_{8}{ }^{*}, \mathrm{Li}_{2} \mathrm{~S}_{6}{ }^{*}, \mathrm{Li}_{2} \mathrm{~S}_{4}{ }^{*}$ to $\mathrm{Li}_{2} \mathrm{~S}_{2}{ }^{*}$ intermediates on the $\mathrm{In}_{2} \mathrm{O}_{3}$ and graphene substrates. or clean graphene). As shown in Figure 4g, there is a much higher binding energy of $-3.07 \mathrm{eV}$ between $\operatorname{In}_{2} \mathrm{O}_{3}$ and $\mathrm{S}_{8}$, compared to that of $-0.74 \mathrm{eV}$ of clean graphene substrate. Elemental sulfur $\left(\mathrm{S}_{8}\right)$ is easy to be adsorbed onto the $\operatorname{In}_{2} \mathrm{O}_{3}$ surface due to the higher binding energy resulting from the strong In-S bonds, which slows down the conversion from $\mathrm{S}_{8}$ to $\mathrm{Li}_{2} \mathrm{~S}_{8}$ to some extent. Finally, we build the reaction pathways by considering the $\mathrm{Li}_{2} \mathrm{~S}_{8}{ }^{*}, \mathrm{Li}_{2} \mathrm{~S}_{6}{ }^{*}, \mathrm{Li}_{2} \mathrm{~S}_{4}{ }^{*}$ and $\mathrm{Li}_{2} \mathrm{~S}_{2}{ }^{*}$ polysulfide intermediates (Figure 4h). As expected, the energy barrier for polysulfide conversion is greatly reduced 
with the catalyst. For example, there is an obvious energy barrier of $0.47 \mathrm{eV}$ for the conversion from $\mathrm{Li}_{2} \mathrm{~S}_{6}{ }^{*}$ to $\mathrm{Li}_{2} \mathrm{~S}_{4}{ }^{*}$ on the clean graphene substrate. In contrast, this conversion on the $\operatorname{In}_{2} \mathrm{O}_{3}$ catalyst is only $0.13 \mathrm{eV}$, confirming that the catalyst accelerates the redox conversions from the long-chain to short-chain polysulfides.

Reversible redox reaction with the LiInS $_{2}$ intermediates. The crystalline LiInS $_{2}$ was synthesized (see Experimental section) to further demonstrate how the intermediate works in the $\mathrm{Li}_{2} \mathrm{~S}_{\mathrm{n}}$ conversion, and the XRD pattern (Figure 5a) confirms the orthorhombic $\mathrm{LiInS}_{2}$ structure with a space group of Pna21 (the standard PDF \#361352). ${ }^{43} \mathrm{~A} \mathrm{LiInS}_{2}$-based battery was then assembled with the $\mathrm{LiInS}_{2}$ loaded carbon paper $(\mathrm{CP})$ coupled with a $\mathrm{Li}$ anode and $\mathrm{Li}_{2} \mathrm{~S}_{8}$ catholyte. A $\mathrm{LiInS}_{2}$-free battery for reference was assembled in the same way. Upon discharged to $2.1 \mathrm{~V}$, two new peaks at 288 and $303 \mathrm{~cm}^{-1}$ due to the stretching and torsional movement of S-In bonds in LiInS 2 are detected by Raman spectroscopy except for the original characteristic peaks (Figure $5 b) .{ }^{42}$ These newly appearing peaks have similar positions to that of $\mathrm{LiInS}_{2}$ detected in in-situ Raman measurement for $\operatorname{In}_{2} \mathrm{O}_{3}$-catalyzed battery as shown in Figure 3a. As expected, it is hard to probe $\mathrm{Li}_{2} \mathrm{~S}_{\mathrm{n}}$ in the Raman spectrum for the LiInS $\mathrm{S}_{2}$-based battery, indicating the greatly accelerated $\mathrm{Li}_{2} \mathrm{~S}_{\mathrm{n}}$ conversion with the $\mathrm{LiInS}_{2}$. It is reasonable that no $\mathrm{LiInS} \mathrm{S}_{2}$ peaks are observed for the $\mathrm{LiInS}_{2}$-free battery from 260 to $310 \mathrm{~cm}^{-1}$, and the peaks corresponding to the $\mathrm{Li}_{2} \mathrm{~S}_{\mathrm{n}}$ at 398,448 and $533 \mathrm{~cm}^{-1}$ are detected, indicating the sluggish conversion. The above results confirm the critical role of $\mathrm{LiInS}_{2}$ intermediates in the fast conversion of $\mathrm{Li}_{2} \mathrm{~S}_{\mathrm{n}}$.

The evolution of the $\mathrm{LiInS}_{2}$ intermediate can be also demonstrated by the X-ray photoelectron spectra (XPS) spectra at the fully discharged state of the $\mathrm{In}_{2} \mathrm{O}_{3}$-catalyzed cathode. The In $3 \mathrm{~d}$ core-level XPS spectrum for the fresh cathode shows typical doublets at 445.0 and $452.6 \mathrm{eV}$ for $\operatorname{In}_{2} \mathrm{O}_{3}$. After complete discharge, two additional signals at 445.2 and $452.8 \mathrm{eV}$ are detected, which are possibly attributed to the binding of $\mathrm{In}-\mathrm{S}$ in $\mathrm{LiInS}_{2}$ when compared to the XPS spectrum for pure $\mathrm{LiInS}_{2}$ (Figure 5c). In addition, the doublets for the $\mathrm{S} 2 \mathrm{p}$ core bands of the discharged $\mathrm{In}_{2} \mathrm{O}_{3}-$ catalyzed cathode can be deconvoluted into four phases; the signals at $169.0,170.0 \mathrm{eV}$ and $167.1,168.1 \mathrm{eV}$ fitted can be assigned to sulfate and sulfite, and the relatively weak peaks can be attributed to $\mathrm{Li}_{2} \mathrm{~S}$ and the LiInS $\mathrm{S}_{2}$ intermediate, respectively.

The ADF-STEM images with line scan elemental maps were used to characterize the $\operatorname{In}_{2} \mathrm{O}_{3}$-catalyzed cell before and after charging. The comparison of the cases for the fresh (Fig. 5f) and the fully charged (Fig. 5g) $\operatorname{In}_{2} \mathrm{O}_{3}$-catalyzed cells show that sulfur is enriched at the $\mathrm{In}_{2} \mathrm{O}_{3}$ surface for the fully charged case, which coincide well with the in-situ Raman results suggesting that sulfur is completely converted back to crystalline S. In addition, according to the XPS results (Figure $5 \mathrm{~d})$, the disappearance of $\mathrm{Li}_{2} \mathrm{~S}$ peak $(160.0 \mathrm{eV}, 161.0 \mathrm{eV})$ together with the appearance of $\mathrm{S}$ peak 
$1 \quad(164.2 \mathrm{eV}, 165.2 \mathrm{eV})$ at the fully charged state confirm high reversibility of the sulfur species during the discharge-

2 charge cycle. In a sharp contrast, $\mathrm{Li}_{2} \mathrm{~S}$ peaks were detected both in the discharged and charged states from the $\mathrm{In}_{2} \mathrm{O}_{3^{-}}$

3 free cell (Figure 5e) suggesting poor reversibility of the insoluble discharge products. ${ }^{14}$ In short, both active sulfur and $\mathrm{In}_{2} \mathrm{O}_{3}$ catalysts are fully reversible, and the $\mathrm{In}_{2} \mathrm{O}_{3}$ catalyst together with the $\mathrm{LinS}_{2}$ intermediates plays a crucial role in accelerating $\mathrm{Li}_{2} \mathrm{~S}_{\mathrm{n}}$ conversion and specially in the charge process, fully converts them into elemental sulfur.
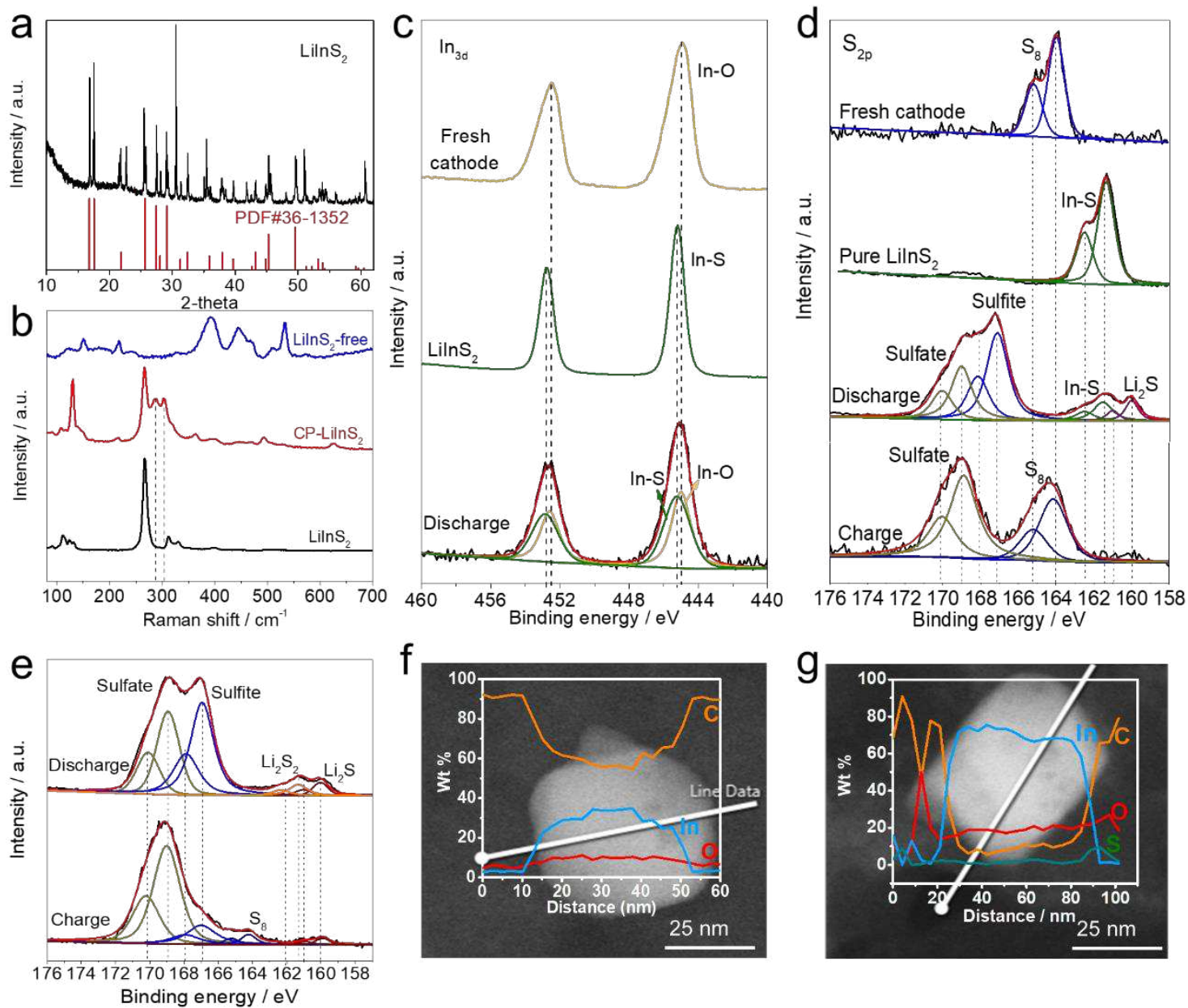

Figure 5. Conversion of polysulfide $\left(\mathrm{Li}_{2} \mathrm{~S}_{\mathbf{n}}\right)$ with $\mathrm{LiInS}_{2}$ as a catalysis intermediate. (a) XRD patterns of the prepared LiInS 2 ; (b) Raman spectra (irradiated with $532 \mathrm{~nm}$ laser) of the synthesized LiInS $2, \mathrm{LiInS}_{2}$-free and LiInS 2 -based cathode $(\mathrm{CP}$-LiInS 2$)$ discharged at $2.1 \mathrm{~V}$; (c) XPS spectra for the $3 \mathrm{~d}$ level of In: pristine $\mathrm{In}_{2} \mathrm{O}_{3}$, prepared $\mathrm{LiInS}_{2}$ and the $\operatorname{In}_{2} \mathrm{O}_{3}$ cathode in the fully discharged state; (d) $\mathrm{S}_{2 \mathrm{p}}$ XPS spectra of fresh cathode, pure $\mathrm{LiInS}_{2}$ and the $\mathrm{In}_{2} \mathrm{O}_{3}$-catalyzed cathode in the fully discharged and charged state; (e) $\mathrm{S}_{2 p}$ XPS spectra of the $\mathrm{In}_{2} \mathrm{O}_{3}$-free cathode in the fully discharged and charged state; ADF-STEM images and corresponding line scan elemental mapping of (f) fresh $\mathrm{In}_{2} \mathrm{O}_{3}$ and $(\mathrm{g})$ the $\mathrm{In}_{2} \mathrm{O}_{3}$-catalyzed cathode in the fully charged state.

Understanding of deactivation of the $\operatorname{In}_{2} \mathrm{O}_{3}$ catalysts. To gain insight on the stability of $\operatorname{In}_{2} \mathrm{O}_{3}$ nanocatalyst, a critical operation condition was carried out that is a long run battery test at an ultrahigh rate of 4.0 C. As shown in

Figure 6a and Supplementary Fig. 21, the $\operatorname{In}_{2} \mathrm{O}_{3}$-catalyzed battery demonstrates outstanding stability with negligible 
capacity decay up to 1000 cycles. Unfortunately, the battery is then presented capacity decay (Supplementary Fig. 22), which implies the deactivation of $\operatorname{In}_{2} \mathrm{O}_{3}$ nanocatalyst due to the surface "poising". Figure $6 \mathrm{~b}$ shows the S $2 p$ XPS spectra of $\operatorname{In}_{2} \mathrm{O}_{3}$-catalyzed cathode after the first cycle of discharge. As expected, the $\mathrm{S} 2 \mathrm{p}$ core level bands for the discharge product $\mathrm{Li}_{2} \mathrm{~S}$ and the $\mathrm{LiInS}_{2}$ intermediates (In-S bond) are obviously detected on the catalyst surface, indicative of a fast conversion of $\mathrm{Li}_{2} \mathrm{~S}_{\mathrm{n}}$ in presence of $\mathrm{LiInS}_{2}$. In a sharp contrast, the $\mathrm{S} 2 \mathrm{p}$ core level bands for $\mathrm{Li}_{2} \mathrm{~S}$ and $\mathrm{LiInS}_{2}$ (In-S bond) are undetected in the cathode over 1000 cycles of discharge. Instead, the signals at 163.5 and $164.5 \mathrm{eV}$ corresponding to the $\mathrm{S} 2 \mathrm{p}$ core level bands for accumulated $\mathrm{Li}_{2} \mathrm{~S}_{\mathrm{n}}$ were detected (Figure $6 \mathrm{~b}$ ), suggesting that most of $\mathrm{Li}_{2} \mathrm{~S}_{\mathrm{n}}$ are not converted into $\mathrm{Li}_{2} \mathrm{~S}$. The high coverage of $\operatorname{In}_{2} \mathrm{O}_{3}$ particles with the irreversible sulfate (excess oxidation product, see Supplementary Fig. 16 e, f) is the possible reason to inhibit the formation of $\operatorname{LinS}_{2}$ intermediates, thereby resulting in deactivation of the catalyst and the slow conversion of $\mathrm{Li}_{2} \mathrm{~S}_{\mathrm{n}}$ to $\mathrm{Li}_{2} \mathrm{~S}$. In fact, the high coverage of strong adsorbate on the surface is a general reason for deactivation of a solid catalyst in a Scontaining reaction, ${ }^{44}$ which indicates, in spite of accelerated conversion of $\mathrm{Li}_{2} \mathrm{~S}_{\mathrm{n}}$ to $\mathrm{Li}_{2} \mathrm{~S}$, the catalyst poising is still an important issue to overcome for the design of high-performance catalyst for Li-S batteries.
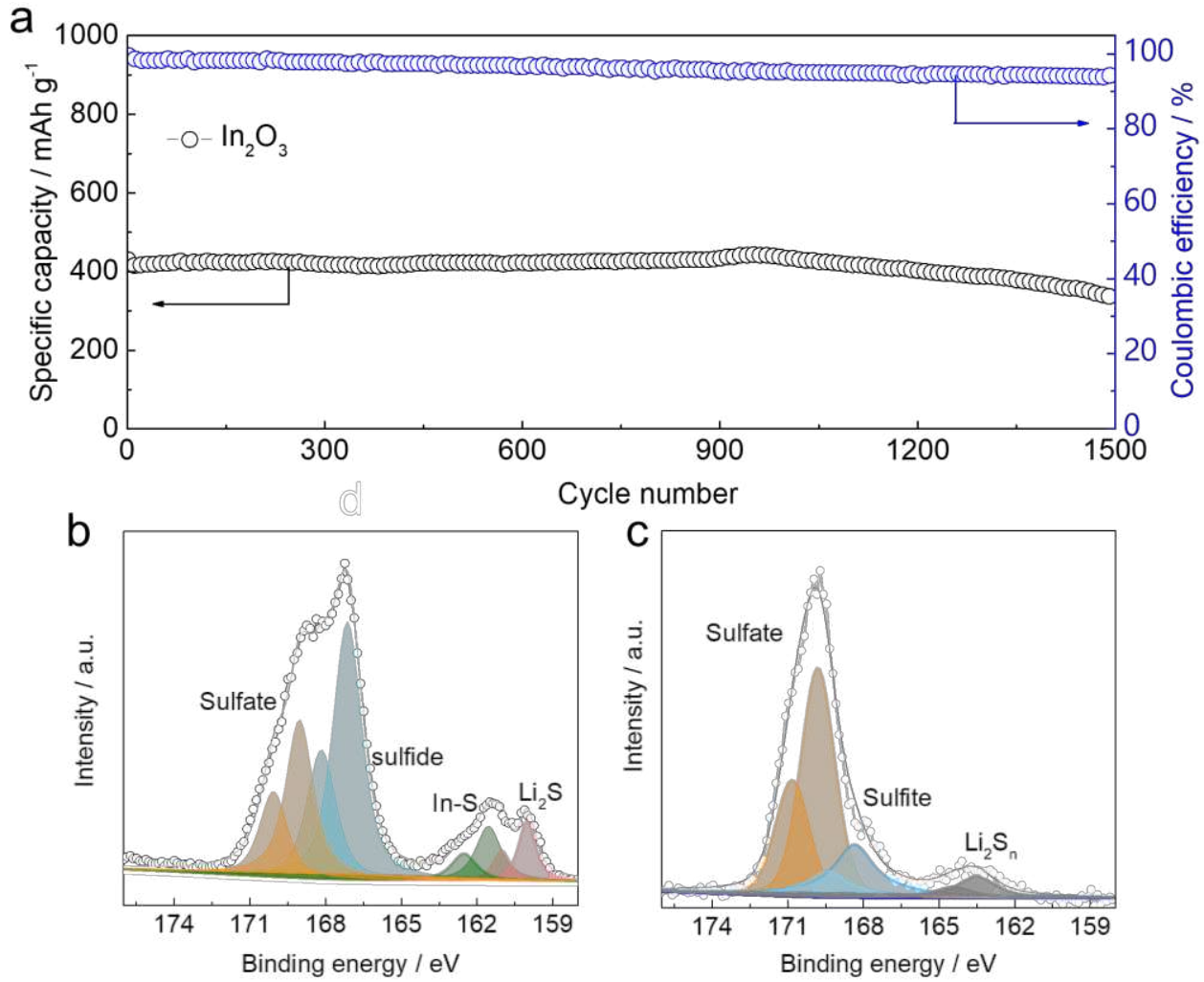

Figure 6. The deactivation of $\operatorname{In}_{2} \mathrm{O}_{3}$ catalyst. (a) cycling performance of $\operatorname{In}_{2} \mathrm{O}_{3}$-catalyzed battery at $4.0 \mathrm{C}$ with a catalyst deactivation over 1000 cycles; $\mathrm{S}_{2 \mathrm{p}}$ XPS spectra of $\operatorname{In}_{2} \mathrm{O}_{3}$-catalyzed cathode for the $1^{\text {st }}(\mathrm{b})$ and $1000^{\text {th }}$ cycle $(\mathrm{b})$ in the fully discharged states. 


\section{Discussion}

We propose the selective catalysis as a remedy for the shuttle effect for Li-S batteries. Targeting at different steps in the consecutive solid-liquid-solid reaction, the proof-of-concept catalyst, $\operatorname{In}_{2} \mathrm{O}_{3}$, slows down the solid-liquid reaction, dissolution of elemental sulfur to soluble $\mathrm{Li}_{2} \mathrm{~S}_{\mathrm{n}}$ while accelerates the liquid-solid reaction, deposition of $\mathrm{Li}_{2} \mathrm{~S}_{\mathrm{n}}$ into insoluble discharge product $\mathrm{Li}_{2} \mathrm{~S} / \mathrm{Li}_{2} \mathrm{~S}_{2}$, which basically reduces the accumulation of soluble polysulfide in the electrolyte and represents a root solution for tackling the shuttle effect. The selective catalysis is featured by the changes of activation energies $(E \mathrm{a})$ and kinetic currents in the consecutive redox reaction, modified reaction pathway together with the probed $\mathrm{LiInS}_{2}$ intermediates demonstrated by the in-situ Raman spectra, as well as the catalyst deactivation after 1000 cycles. The $\mathrm{LiInS}_{2}$ intermediates probed by experimental study and computational simulation has been proved to accelerate the SRR and SER, and especially, substantially promote the conversion from $\mathrm{Li}_{2} \mathrm{~S}$ to $\mathrm{Li}_{2} \mathrm{~S}_{\mathrm{n}}$, and finally to elemental sulfur, increasing the conversion. As a result, the Li-S batteries work steadily with negligible capacity decay over 1000 cycles at an ultrahigh rate of $4.0 \mathrm{C}$. Moreover, with a high areal sulfur loading $\left(\sim 9.0 \mathrm{mg} \mathrm{cm}{ }^{-2}\right)$ yet a low electrolyte/sulfur ratio $\left(8 \mu \mathrm{L} \mathrm{mg}^{-1}\right)$, the battery still displays a high initial areal capacity up to $9.4 \mathrm{mAh} \mathrm{cm}^{-2}$ at a current density of $0.9 \mathrm{~mA} \mathrm{~cm}^{-2}$. This work featured with selective catalysis, we hope, provides a valuable inspiration for the rational design of catalysts in Li-S batteries and finally accelerates the practical use and commercialization of Li-S batteries by basically suppressing the loss of active sulfur and reducing the amount of required electrolyte.

\section{Methods}

Synthesis of CNT/S composites. The carbon nanotube/sulfur composites (CNT/S) were prepared by a simple melt-diffusion method. ${ }^{27}$ In a typical procedure, the CNTs and sulfur (99.99\% pure metal basis, Aladdin) were mixed in the desired ratio. Then the powder was grounded and heated under an ambient atmosphere at $155^{\circ} \mathrm{C}$ for $12 \mathrm{~h}$.

Synthesis of the GO-In $\mathrm{O}_{3}$ composites. Graphite oxide (GO) was synthesized from natural graphite by a modified Hummers method as reported previously. ${ }^{45}$ Commercial $\mathrm{In}_{2} \mathrm{O}_{3} \mathrm{NPs}$ and a graphene oxide suspension $\left(6.5 \mathrm{mg} \mathrm{mL}^{-1}\right)$ with the precalculated target compositions were dispersed in the water ethanol mixtures and a homogenized $\mathrm{GO}-\mathrm{In}_{2} \mathrm{O}_{3}\left(2.0 \mathrm{mg} \mathrm{mL}^{-1}\right)$ liquid was formed by sonication for $2 \mathrm{~h}$.

Synthesis of $\mathrm{In}_{2} \mathrm{O}_{3}-\mathbf{G}-\mathbf{C N T} / \mathbf{S}, \mathbf{G}-\mathbf{C N T} / \mathbf{S}$, and G-In $\mathbf{O}_{3}$ composites. The homogenized GO- $\mathrm{In}_{2} \mathrm{O}_{3}\left(2.0 \mathrm{mg} \mathrm{mL}^{-1}\right)$ suspension was added to the $\mathrm{CNT} / \mathrm{S}$ composites under continuous ultrasonication and then a certain amount of L-ascorbic acid sodium salt as the reducing 

sample was rinsed with deionized water several times and a stiff rod-like $\mathrm{In}_{2} \mathrm{O}_{3}-\mathrm{G}-\mathrm{CNT} / \mathrm{S}$ composite was formed after drying. G-CNT/S and $\mathrm{G}-\mathrm{In}_{2} \mathrm{O}_{3}$ composites were synthesized using a similar process to that for the $\operatorname{In}_{2} \mathrm{O}_{3}-\mathrm{G}-\mathrm{CNT} / \mathrm{S}$ composite without adding $\mathrm{In}_{2} \mathrm{O}_{3}$ or a $\mathrm{CNT} / \mathrm{S}$ composite.

Assembly of symmetric dummy cells. $\mathrm{Li}_{2} \mathrm{~S}$ and $\mathrm{S}$ in amounts corresponding to the nominal stoichiometry of $\mathrm{Li}_{2} \mathrm{~S}_{6}$ were added to a 1 : $1(\mathrm{v} / \mathrm{v}) \mathrm{DOL} / \mathrm{DME}$ mixture and stirred overnight at $50{ }^{\circ} \mathrm{C}$. The concentration of the $\mathrm{Li}_{2} \mathrm{~S}_{6}$ solution prepared was $0.1 \mathrm{~mol} \mathrm{~L}^{-1}$. The $\mathrm{CP}$ was punched into small disks with a diameter of $10.0 \mathrm{~mm} .0 .3 \mathrm{mg} \mathrm{cm}-2 \mathrm{G}-\mathrm{In}_{2} \mathrm{O}_{3}$ and graphene powders was loaded onto CP disks and were denoted as $\mathrm{In}_{2} \mathrm{O}_{3}$-based and $\mathrm{In}_{2} \mathrm{O}_{3}$-free electrodes, respectively. The typical loading procedure involved a sequence of ultrasonic dispersing $\mathrm{In}_{2} \mathrm{O}_{3}$-based powders in NMP, dropwise adding the suspension onto $\mathrm{CP}$ disks, and then drying the electrodes at $55^{\circ} \mathrm{C}$ for 12.0 h. Two identical electrodes were assembled into a standard 2032 coin cell, and $20.0 \mu \mathrm{L} \mathrm{Li}_{2} \mathrm{~S}_{6}$ electrolyte was added.

Cell assembly and electrochemical measurements. The $\mathrm{In}_{2} \mathrm{O}_{3}$-based cathodes were prepared by mixing $\operatorname{In}_{2} \mathrm{O}_{3}-\mathrm{G}-\mathrm{CNT} / \mathrm{S}$ powder $(95$ $\mathrm{wt} \%)$ and poly (vinylidene fluoride) $(5 \mathrm{wt} \%)$ as a binder dissolved in N-methyl-2-pyrrolidone (NMP) to form a slurry, which was then coated onto an $\mathrm{Al}$ foil and vacuum-dried at $55^{\circ} \mathrm{C}$ for $12 \mathrm{~h}$. For reference, we also fabricated $\operatorname{In}_{2} \mathrm{O}_{3}$-free cathodes with G-CNT/S powder The foil was then cut into a circle of diameter $10 \mathrm{~mm}$ for use as the cathode. CR2032 coin cells were assembled using the coated Al foil as the current collector for cathode, a lithium metal foil anode, Celgard 2400 as the separator, and $1.0 \mathrm{M}$ lithium bistrifluoromethanesulphonylimide (LiTFSI) dissolved in 1, 3-dioxolane and 1, 2-dimethoxyethane (DOL: DME, 1:1 vol) with 1.0 wt\% $\mathrm{LiNO}_{3}$ additive as the electrolyte. The electrolyte/sulfur ratios were about 20,10 and $8 \mu \mathrm{L} \mathrm{mg}^{-1}$ for the electrodes with sulfur loadings of $1.0,5.9$ and $9.0 \mathrm{mg} \mathrm{cm}^{-2}$, respectively.

The galvanostatic discharge/charge measurements were conducted using a Neware battery test system. The cathode specific capacities were normalized only by the mass of sulfur, as per common practice. The charge-discharge voltage range was $1.7-2.7 \mathrm{~V}\left(\mathrm{vs} . \mathrm{Li}^{+} / \mathrm{Li}\right.$ ). $\mathrm{CV}$ curves were obtained using an Autolab workstation at a scan rate of $0.1 \mathrm{mV} \mathrm{s}^{-1}$ with a potential range of $1.7-2.7 \mathrm{~V}\left(\mathrm{vs}\right.$. $\left.\mathrm{Li}^{+} / \mathrm{Li}\right)$ and EIS was conducted using an Autolab workstation with a frequency range of $0.01-10^{5} \mathrm{~Hz}$.

Measurement for the nucleation of lithium sulfide $\left(\mathbf{L i}_{2} \mathbf{S}\right)$. A Li ${ }_{2} \mathrm{~S}_{8}$ solution $\left(0.2 \mathrm{~mol} \mathrm{~L}^{-1}\right)$ was used as the electrolyte and was prepared by combining stoichiometric amounts of lithium sulfide and sulfur powder in tetraglyme under vigorous magnetic stirring. The CP was punched into circular disks with diameters of $10 \mathrm{~mm}$ and used as the current collector to load $0.3 \mathrm{mg} \mathrm{G}$ or G-In $2 \mathrm{O}_{3}$ powders for cell assembly and a lithium foil was used as the anode. $20 \mu 1 \mathrm{Li}_{2} \mathrm{~S}_{8}$ electrolyte was first distributed in the cathode and then $20 \mu 1$ of the electrolyte without $\mathrm{Li}_{2} \mathrm{~S}_{8}$ was dropped onto the lithium anode compartment. The assembled cells were first discharged galvanostatically at $0.112 \mathrm{~mA}$ to $2.06 \mathrm{~V}$ and then discharged potentiostatically at $2.05 \mathrm{~V}$ for $\mathrm{Li}_{2} \mathrm{~S}$ nucleation and growth. The potentiostatic discharge was terminated when the current fell below $10^{-5} \mathrm{~A} \cdot{ }^{23}$

Synthesis of the crystalline LiInS 2 . The commercial LiF (98+\%, Alfa) and $\operatorname{In}_{2} \mathrm{~S}_{3}(99.99 \%$ metal basis, Aladdin) were mixed with a molar ratio of 2:1. Then the powder was grounded and heated under vacuum atmosphere at $750{ }^{\circ} \mathrm{C}$ for $5 \mathrm{~h}$ and cooled at room temperature to obtain the crystalline $\mathrm{LiInS}_{2}$.

CP-LiInS 2 Cell assembly. The $\mathrm{CP}$ was punched into circular disks with diameters of $10 \mathrm{~mm}$ and used as the current collector to load 
$1.0 \mathrm{mg} \mathrm{LiInS} 2$ powders for cell assembly and a lithium foil was used as the anode. $20 \mu \mathrm{Li}_{2} \mathrm{~S}_{8}$ electrolyte was first distributed in the cathode and then $20 \mu \mathrm{l}$ of the electrolyte without $\mathrm{Li}_{2} \mathrm{~S}_{8}$ was dropped onto the lithium anode compartment. LiInS $\mathrm{S}_{2}$-free cell was assembled as the same procedure using the $\mathrm{CP}$ as the current collector without $\mathrm{LinS}_{2}$ powders

In-Situ Raman Spectroscopy. Li-S coin cells with a quartz window and a hole on the stainless steel were used for the in-situ Raman spectroscopy analysis at $532 \mathrm{~nm}$ Laser (Supplementary Fig 23). The sulfur cathodes were prepared by mixing $\operatorname{In}_{2} \mathrm{O}_{3}$-based/free powder (95 $\mathrm{wt} \%)$ and poly tetra fluoroethylene (5 wt\%) dissolved in ethanol as a binder to form a self-supporting electrode and vacuum-dried at $55{ }^{\circ} \mathrm{C}$ for $12 \mathrm{~h}$. The cells were tested at a rate of $0.05 \mathrm{C}$.

Computational Section. All calculations in this work were carried out using density functional theory (DFT) method as implemented in the VASP code. The electronic exchange-correlation energy was modeled using the Perdew-Burke-Ernzerhof (PBE) functional within the generalized gradient approximation (GGA). The projector augmented wave (PAW) method was used to describe the ionic cores. For the plane-wave expansion, a $450 \mathrm{eV}$ kinetic energy cut-off was used after testing a series of different cut-off energies. A Monkhorst-Pack $3 \times 3 \times 1$ k-point grid was used to sample the Brillouin zone. The convergence criterion for the electronic structure iteration was set to be $10^{-4} \mathrm{eV}$, and that for geometry optimizations was set to be $0.01 \mathrm{eV} \AA^{-1}$ on force. A Gaussian smearing of $0.1 \mathrm{eV}$ was applied during the geometry optimization and for the total energy computations. For the density of states (DOS) computations, a tetrahedron method with Blöchl correction was employed. Denser k-points $(5 \times 5 \times 1)$ were used to improve the quality of DOS computations. The projected DOS patterns were extracted from the total DOS results.

Structural Characterization. SEM was performed on a Hitachi S4800 (Hitachi Japan) instrument. ADF-STEM measurements were conducted on a Hitachi HF5000 coupled with an energy dispersive spectrometer (EDS). The Raman spectra were recorded on a MicroRaman system (LabRAM HR spectrometer, Horiba) with an Olympus BX microscope and an argon ion laser (532 nm). XRD patterns were collected on a Bruker D-8 diffractometer $(\mathrm{Cu} K \alpha$ radiation, $\lambda=0.154 \mathrm{~nm})$ at room temperature. TG (Rigaku, Japan) was performed in air from room temperature to $500^{\circ} \mathrm{C}$ at a heating rate of $10{ }^{\circ} \mathrm{C}$ per minute to calculate the amount of sulfur in the hybrids. Nitrogen adsorption measurement was conducted at $77 \mathrm{~K}$ using a BEL-mini instrument (BEL Inc., Japan). The specific surface area was obtained by Brunauer-Emmett-Teller (BET) analysis of the adsorption isotherm. XPS data were recorded by an ESCALAB 250Xi (Thermo Fisher) with a monochromatic Al Ka source to analyze the surface species and their chemical states.

\section{Data availability}

The data supporting the findings of this work are available within the article and its Supplementary Information files. All other relevant data supporting the findings of this study are available from the corresponding author on request.

\section{References}

1. Bruce PG, Freunberger SA, Hardwick LJ, Tarascon JM. Li-O $\mathrm{O}_{2}$ and Li-S batteries with high energy storage. Nature Mater.11, 19-29 (2011). 

1,16132 (2016).

3 3. Fang R, Zhao S, Sun Z, Wang DW, Cheng HM, Li F. More Reliable Lithium-Sulfur Batteries: Status, Solutions, and Prospects. Adv. Mater. 29, 1606823 (2017).

4. Bhargav A, He J, Gupta A, Manthiram A. Lithium-Sulfur Batteries: Attaining the Critical Metrics. Joule 4, 285$291(2020)$.

5. Bai S, Liu X, Zhu K, Wu S, Zhou H. Metal-organic framework-based separator for lithium-sulfur batteries. Nat. Energy 1,16094 (2016).

6. Xue W, et al. Intercalation-conversion hybrid cathodes enabling Li-S full-cell architectures with jointly superior gravimetric and volumetric energy densities. Nat. Energy 4, 374-382 (2019).

7. Ji X, Lee KT, Nazar LF. A highly ordered nanostructured carbon-sulphur cathode for lithium-sulphur batteries. Nature Mater. 8, 500-506 (2009).

8. Pei F, et al. Self-supporting sulfur cathodes enabled by two-dimensional carbon yolk-shell nanosheets for highenergy-density lithium-sulfur batteries. Nat. Commun. 8, 482 (2017).

9. Tao X, et al. Balancing surface adsorption and diffusion of lithium-polysulfides on nonconductive oxides for lithium-sulfur battery design. Nat. Commun. 7, 11203 (2016).

10. Yang A, et al. Electrochemical generation of liquid and solid sulfur on two-dimensional layered materials with distinct areal capacities. Nature Nanotech. 15, 231-237 (2020).

11. Li G, et al. Chemisorption of polysulfides through redox reactions with organic molecules for lithium-sulfur batteries. Nat. Commun. 9, 705 (2018).

12. Zhang J, et al. Double-Shelled Nanocages with Cobalt Hydroxide Inner Shell and Layered Double Hydroxides Outer Shell as High-Efficiency Polysulfide Mediator for Lithium-Sulfur Batteries. Angew. Chem., Int. Ed. 55, 39826 (2016).

13. Guo L, et al. Enhanced Multiple Anchoring and Catalytic Conversion of Polysulfides by Amorphous $\mathrm{MoS}_{3}$ Nanoboxes for High-Performance Li-S Batteries. Angew. Chem., Int. Ed. 59, 13071-13078 (2020).

14. Al Salem H, Babu G, Rao CV, Arava LM. Electrocatalytic Polysulfide Traps for Controlling Redox Shuttle Process of Li-S Batteries. J. Am. Chem. Soc. 137, 11542-11545 (2015).

15. Liu D, et al. Catalytic Effects in Lithium-Sulfur Batteries: Promoted Sulfur Transformation and Reduced Shuttle Effect. Adv. Sci. 5, 1700270 (2018). 
16. Zhou G, et al. Catalytic oxidation of $\mathrm{Li}_{2} \mathrm{~S}$ on the surface of metal sulfides for Li-S batteries. Proc. Natl. Acad. Sci. U. S. A. $114,840-845$ (2017).

17. Chen T, et al. Self-Templated Formation of Interlaced Carbon Nanotubes Threaded Hollow $\mathrm{Co}_{3} \mathrm{~S}_{4} \mathrm{Nanoboxes}$ for High-Rate and Heat-Resistant Lithium-Sulfur Batteries. J. Am. Chem. Soc. 139, 12710-12715 (2017).

18. Wang R, et al. Bidirectional Catalysts for Liquid-Solid Redox Conversion in Lithium-Sulfur Batteries. Adv. Mater. 2000315 (2020).

19. Zhao M, et al. Activating Inert Metallic Compounds for High-Rate Lithium-Sulfur Batteries Through In Situ Etching of Extrinsic Metal. Angew. Chem. Int. Ed. 58, 3779 -3783 (2019).

20. Sun Z, et al. Conductive porous vanadium nitride/graphene composite as chemical anchor of polysulfides for lithium-sulfur batteries. Nat. Commun. 8, 14627 (2017).

21. Wang J, et al. Double-Shelled Phosphorus and Nitrogen Codoped Carbon Nanospheres as Effcient Polysulfde Mediator for High Performance Lithium-Sulfur Batteries. Adv. Sci. 5, 1800621 (2018).

22. Zhou J, et al. Deciphering the Modulation Essence of p Bands in Co-Based Compounds on Li-S Chemistry. Joule 2, 2681-2693 (2018).

23. Zhong Y, et al. Surface Chemistry in Cobalt Phosphide-Stabilized Lithium-Sulfur Batteries. J. Am. Chem. Soc. 140, $1455-1459$ (2018).

24. Chao Y, et al. 2D MoN-VN Heterostructure To Regulate Polysulfides for Highly Efficient Lithium-Sulfur Batteries. Angew. Chem. Int. Ed. 57, 16703-16707 (2018).

25. Zhou $\mathrm{T}$, et al. Twinborn $\mathrm{TiO}_{2}-\mathrm{TiN}$ heterostructures enabling smooth trapping-diffusion-conversion of polysulfides towards ultralong life lithium-sulfur batteries. Energy Environ. Sci. 10, 1694-1703 (2017).

26. Peng L, et al. A fundamental look at electrocatalytic sulfur reduction reaction. Nature Catalysis, 3, 762-770 (2020).

27. Zheng C, et al. Propelling polysulfides transformation for high-rate and long-life lithium-sulfur batteries. Nano Energy 33, 306-312 (2017).

28. Peng HJ, et al. Enhanced Electrochemical Kinetics on Conductive Polar Mediators for Lithium-Sulfur Batteries. Angew. Chem., Int. Ed. 55, 12990-12995 (2016).

29. Ye Z, Jiang Y, Li L, Wu F, Chen R. A High-Efficiency CoSe Electrocatalyst with Hierarchical Porous Polyhedron Nanoarchitecture for Accelerating Polysulfides Conversion in Li-S Batteries. Adv. Mater. 32, 2002168 (2020). 30. Yuan H, et al. Conductive and Catalytic Triple-Phase Interfaces Enabling Uniform Nucleation in High-Rate 
Lithium-Sulfur Batteries. Adv. Energy Mater. 9, 1802768 (2019).

31. Song Y, et al. Synchronous immobilization and conversion of polysulfides on a $\mathrm{VO}_{2}-\mathrm{VN}$ binary host targeting high sulfur load Li-S batteries. Energy Environ. Sci. 11, 2620-2630 (2018).

32. Pei F, et al. Self-supporting sulfur cathodes enabled by two-dimensional carbon yolk-shell nanosheets for highenergy-density lithium-sulfur batteries. Nat. Commun. 8, 482 (2017).

33. Fang R, et al. Single-wall carbon nanotube network-enabled ultrahigh sulfur-content electrodes for highperformance lithium-sulfur batteries. Nano Energy 42, 205-214 (2017).

34. Zhou G, et al. Theoretical Calculation Guided Design of Single-Atom Catalysts toward Fast Kinetic and LongLife Li-S Batteries. Nano Lett. 20, 1252-1261(2020).

35. Jiao L, et al. Capture and Catalytic Conversion of Polysulfides by In Situ Built $\mathrm{TiO}_{2}-\mathrm{MXene}$ Heterostructures for Lithium-Sulfur Batteries. Adv. Energy Mater. 9. 1900219 (2019).

36. Zhao M, Li BQ, Peng HJ, Yuan H, Wei JY, Huang JQ. Lithium-Sulfur Batteries under Lean Electrolyte Conditions: Challenges and Opportunities. Angew. Chem., Int. Ed, 59, 2-19 (2020).

37. Zhang L, et al. In situ optical spectroscopy characterization for optimal design of lithium-sulfur batteries. Chem. Soc. Rev. 48, 5432-5453 (2019).

38. Meng L, Rao D, Tian W, Cao F, Yan X, Li L. Simultaneous Manipulation of O-Doping and Metal Vacancy in Atomically Thin Zn10In16S34 Nanosheet Arrays toward Improved Photoelectrochemical Performance. Angew. Chem., Int. Ed. 57, 16882-16887 (2018).

39. Chen W, et al. A New Hydrophilic Binder Enabling Strongly Anchoring Polysulfides for High-Performance Sulfur Electrodes in Lithium-Sulfur Battery. Adv. Energy Mater. 8, 1702889 (2018).

40. Hagen M, et al. In-Situ Raman Investigation of Polysulfide Formation in Li-S Cells. J. Electrochem. Soc. 160, A1205-A1214 (2013).

41. Yeon J-T, Jang J-Y, Han J-G, Cho J, Lee KT, Choi N-S. Raman Spectroscopic and X-ray Diffraction Studies of Sulfur Composite Electrodes during Discharge and Charge. J. Electrochem. Soc. 159, A1308-A1314 (2012).

42. Ma T, Sun L, Xu C, Chen Y. First-principles study of lattice dynamics and thermodynamic properties of LiInX (X=S, Se, Te). J. Alloys Compd. 509, 9733-9741 (2011).

43. Magesh M, Vijayakumar P, Arunkumar A, Anandha Babu G, Ramasamy P. Investigation of structural and optical properties in LiInS 2 single crystal grown by Bridgman-Stockbarger method for mid IR laser application. Mater. Chem.Phys. 149, 224-229 (2015). 

Attempt to Deconvolute Geometric and Electronic Poisoning Effects Using Model Catalysts. ACS Catalysis 7, $592-$ 605 (2016). 45. Lv W, et al. Low-Temperature Exfoliated Graphenes: Vacuum-Promoted Exfoliation and Electrochemical Energy Storage. ACS Nano 3, 3730-3736 (2009).

\section{Acknowledgements}

We appreciate support from the National Natural Science Foundation of China (Nos. 51932005 and 21773156), the National Science Fund for Distinguished Young Scholars, China (No. 51525204), the Ministry of Education of China (PCSIRT_IRT_16R49), the Shanghai Sci. \& Tech. and Edu. Committee (19070502700), the National Science Foundation of Tianjin, China (No. 18JCQNJC02300) and the National Key Research and Development Program of China (2018YFE0124500). We sincerely thank Drs. Y. M. Niu and H. Matsumoto for the ADF-STEM measurements and analysis

\section{Author contributions}

Y. W and Q.-H.Y. conceived and supervised the research; W. H. and H. L. designed the experiment and W. H. carried out most of the experiments; H. L. was mainly responsible for the theoretical calculation; C. P. conducted the catalysis mechanism discussion including the activation energy evaluation. J. X. and Y. S. helped with material characterizations and analyzed the results; Y. J. helped with the DFT calculation and the related result discussion; B. Z. helped with the TEM measurements and related analyses. C. Z., W. L., Y. T., and S.-Z. Q. discussed the data and provided the technical support. Q.-H. Y., Y. W., W. H., and H. L. were preparing the manuscript with further inputs from other authors. All authors discussed the results and commented on the manuscript.

\section{Additional information}

Supplementary Information accompanies this paper at http://www.nature.com/reprints.

Competing interests: The authors declare no competing financial interests. 
1 Reprints and permission information is available online at http://npg.nature.com/reprintsandpermissions/

2 Publisher's note: Springer Nature remains neutral with regard to jurisdictional claims in published maps and 3 institutional affiliations. 


\section{Figures}
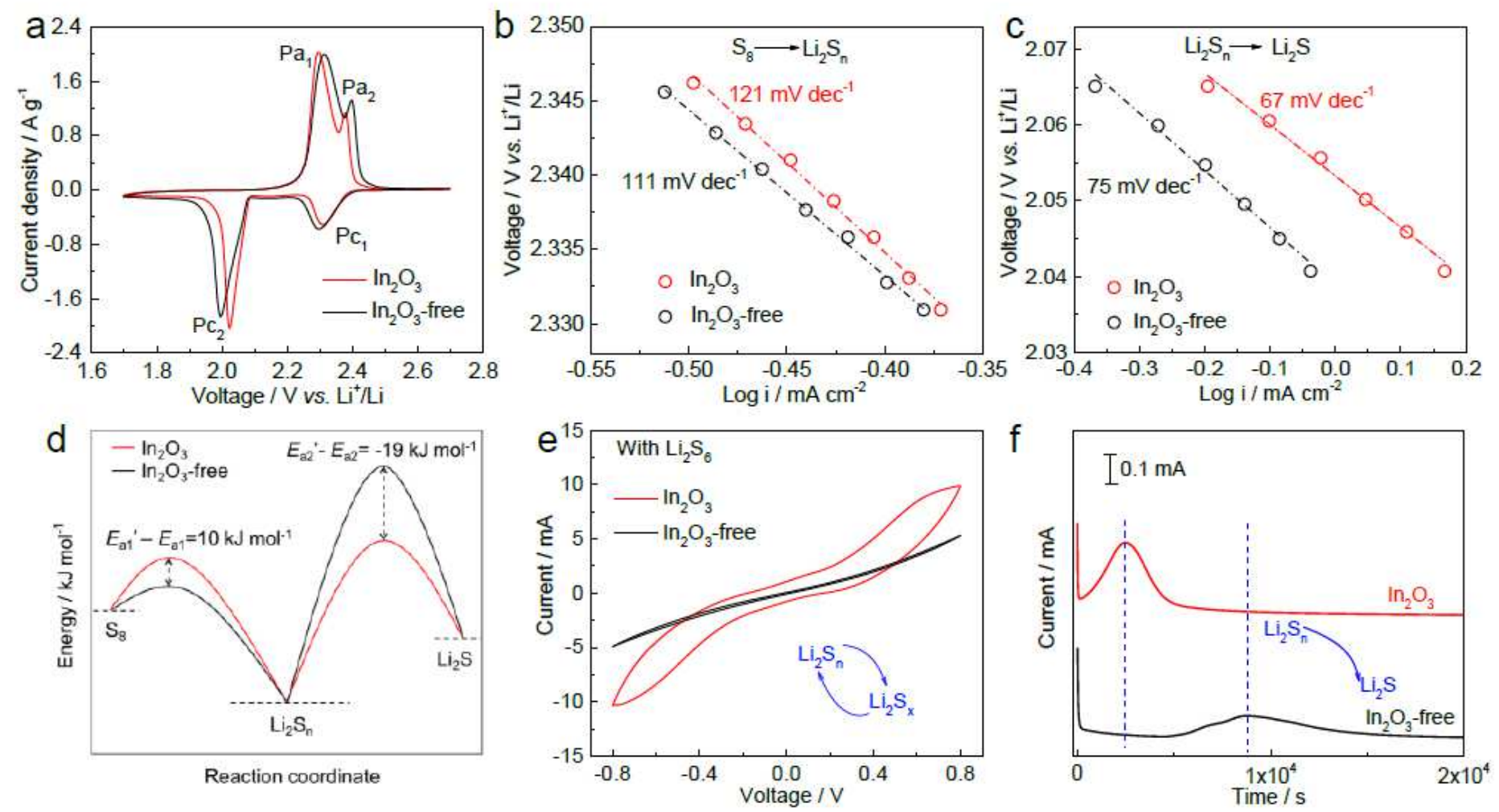

Figure 1

Electrochemical properties of In203-catalyzed cathode in comparison to the In203-free case. (a) the second cycle of CV profiles for the In2O3-catalyzed and In2O3-free Li-S cells at a low scan rate of $0.1 \mathrm{mV}$ s-1 and (b, c) Tafel plots corresponding to the reductions of elemental sulfur to Li2Sn and Li2Sn to Li2S; (d) the relative activation energies of the two sulfur cathodes, where the In203-catalyzed cathode shows a higher energy barrier for the conversion from S8 to Li2Sn, but a lower energy barrier for the Li2Sn-toLi2S conversion, in comparison to the In2O3-free case; (e) CV curves of symmetric dummy cells using In203-catalyzed and In203-free electrodes at a rapid scan rate of $20 \mathrm{mV} \mathrm{s}-1$; (f) potentiostatic discharge curves of a Li2S8/tetraglyme solution at $2.05 \mathrm{~V}$ on the In2O3 catalyzed and In2O3-free electrodes. 

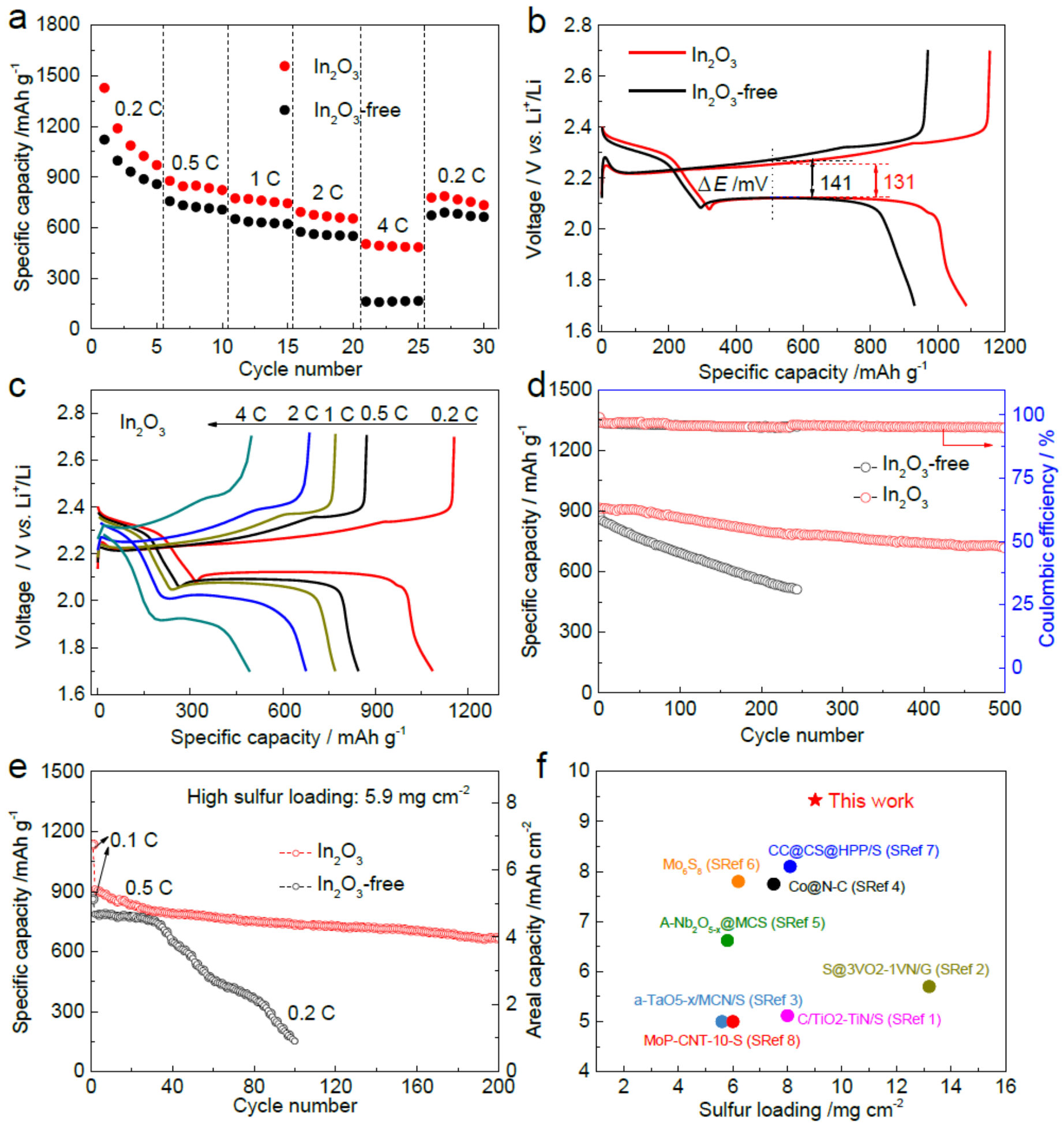

Figure 2

Electrochemical performance of In203-catalyzed Li-S battery in comparison to the In203-free battery. (a) rate performance $(1 \mathrm{C}=1675 \mathrm{~mA} \mathrm{~g}-1)$; (b) galvanostatic discharge-charge profiles at $0.2 \mathrm{C}$; (c) galvanostatic charge-discharge profiles of the In203-catalyzed battery at various current rates; (d) cycling stability at $0.5 \mathrm{C}$; (e) cycling performance with a high sulfur mass loading of $5.9 \mathrm{mg} \mathrm{cm}-2$ at $0.5 \mathrm{C}$ and 0.2 C; (f) a comparison with other sulfur cathodes with electrolyte/sulfur ratios $\leq 8 \mu \mathrm{L} / \mathrm{mg}$ (SRef: Supplementary References). 
- $\mathrm{S}_{8} \quad \Delta \ln _{2} \mathrm{O}_{3} \quad \Delta$ LilnS $_{2} \quad \bullet \mathrm{Li}_{2} \mathrm{~S}_{\mathrm{n}} \quad$ tr $\mathrm{Li}_{2} \mathrm{~S}_{2}$

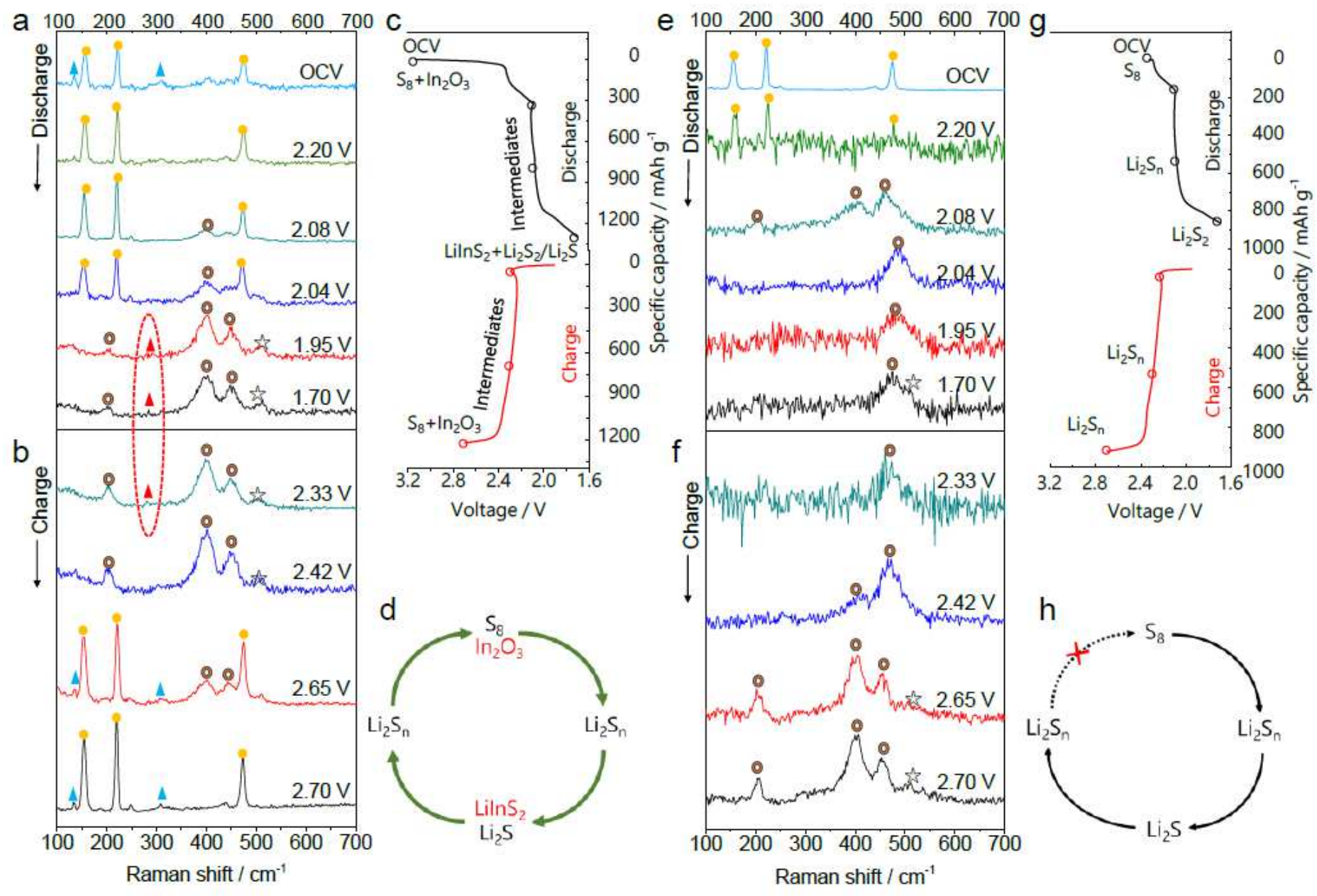

Figure 3

Reaction pathway demonstrated by in-situ Raman measurements. (a, b) Raman spectra of an In203catalyzed battery and (c) the corresponding charge-discharge potentials of the detected substances; (d) a complete cycle of the sulfur redox with In2O3 catalyst; (e, f) Raman spectra of an In203-free battery and (g) the corresponding charge-discharge profile; (h) an incomplete cycle of the sulfur redox free of In203 catalyst. See more details in Supplementary Fig. 20. 
a

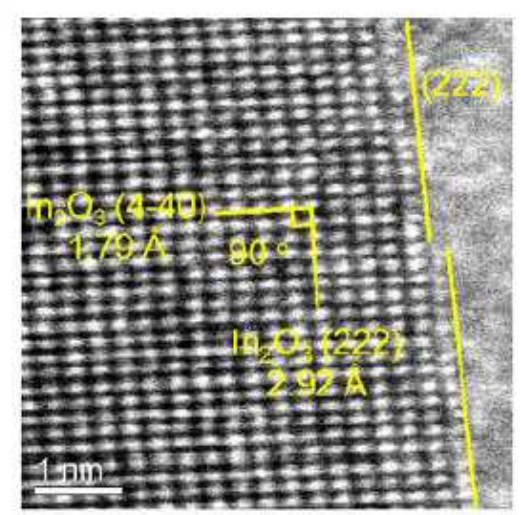

d

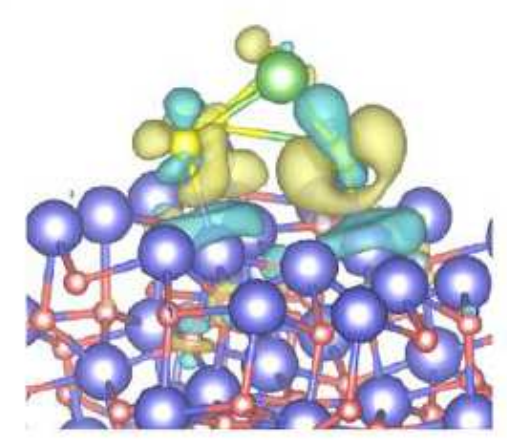

b

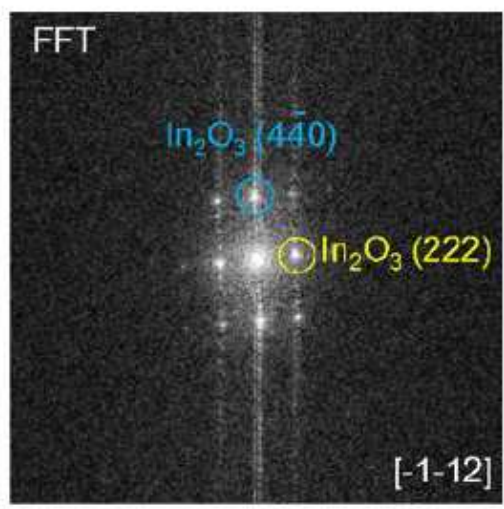

e

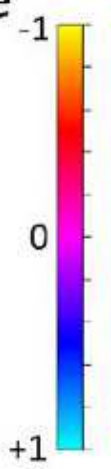

C
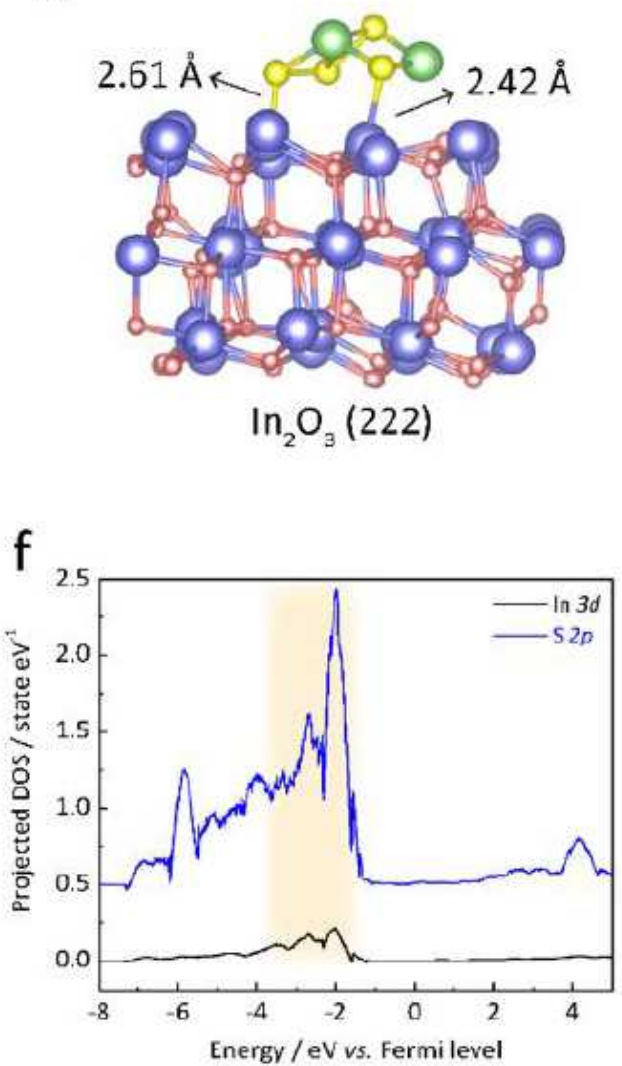

g

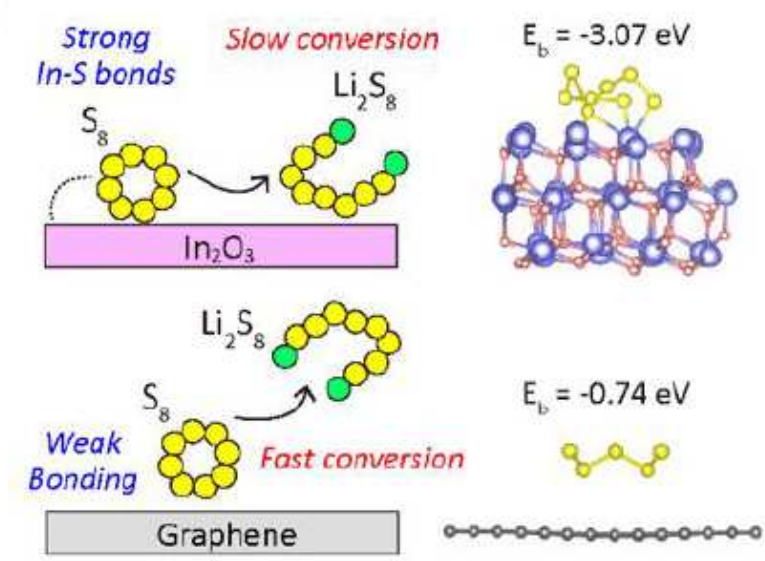

h

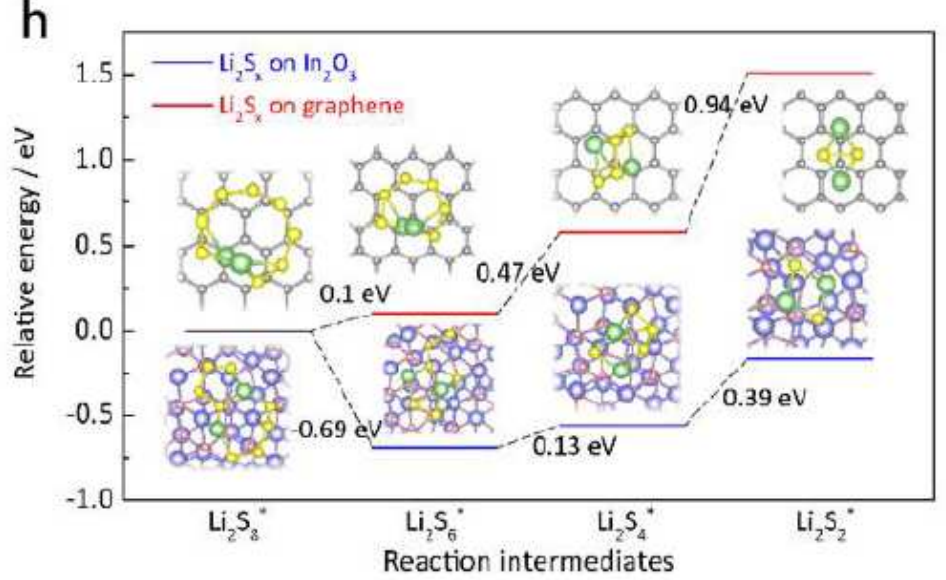

\section{Figure 4}

Computational simulation for the reaction pathway and LilnS2 intermediate. (a) ADF-STEM image of the G-In2O3 hybrids; (b) the superimposed FFTs of In203; (c) the optimized structure of Li2S4 on In2O3 surface; The In-S bond length are 2.42 and $2.61 \AA$, which are very close to the standard In-S bond length in LilnS2 (2.49 Å); (d) 3D charge difference of Li2S4 on In2O3; (e) 2D charge maps between In, 0 and S; (f) the projected DOS of In 3d and S 2p; $(\mathrm{g})$ there is a much high binding energy of $-3.07 \mathrm{eV}$ between In2O3 and S8, compared to that of $-0.74 \mathrm{eV}$ of clean graphene substrate. Hence, S8 is hard to be desorbed from the In2O3 surface, and this slows down the conversion from S8 to Li2S8; (h) the reaction pathway from Li2S8*, Li2S6*, Li2S4* to Li2S2* intermediates on the In2O3 and graphene substrates. 

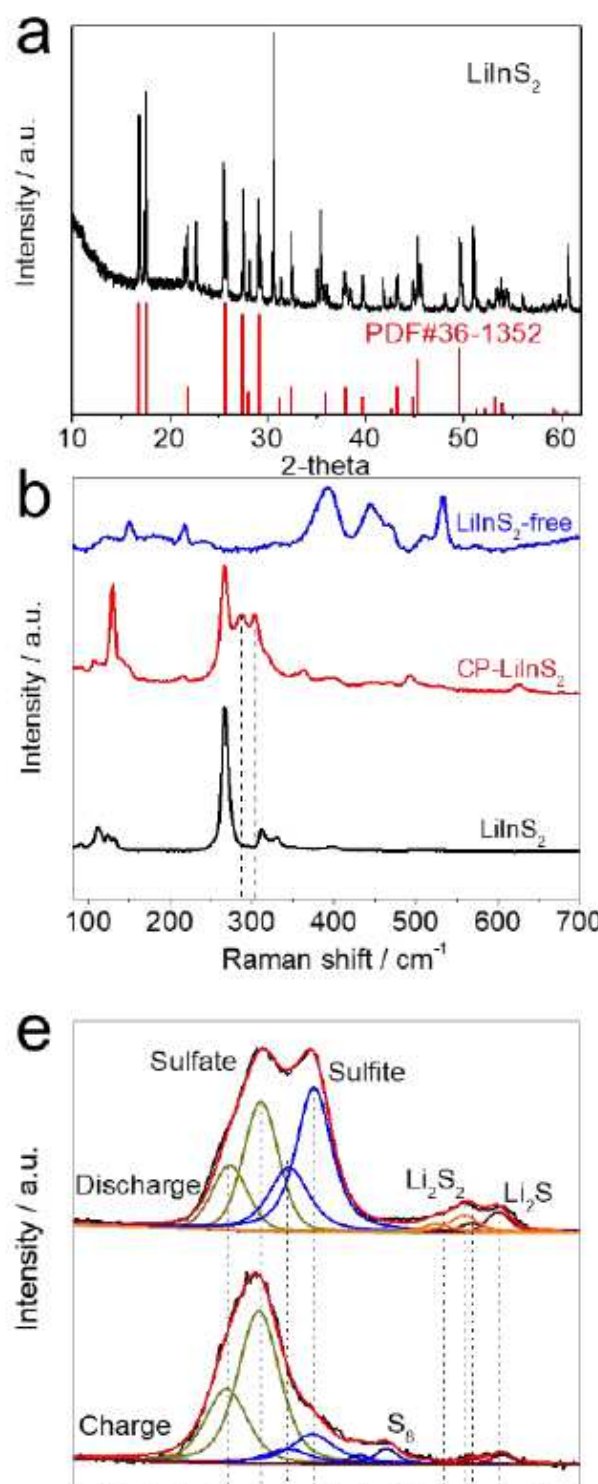

$1 7 6 \longdiv { 1 7 4 1 7 2 1 7 0 1 6 8 1 6 6 1 6 4 1 6 2 1 6 0 1 5 8 }$ Binding energy / eV
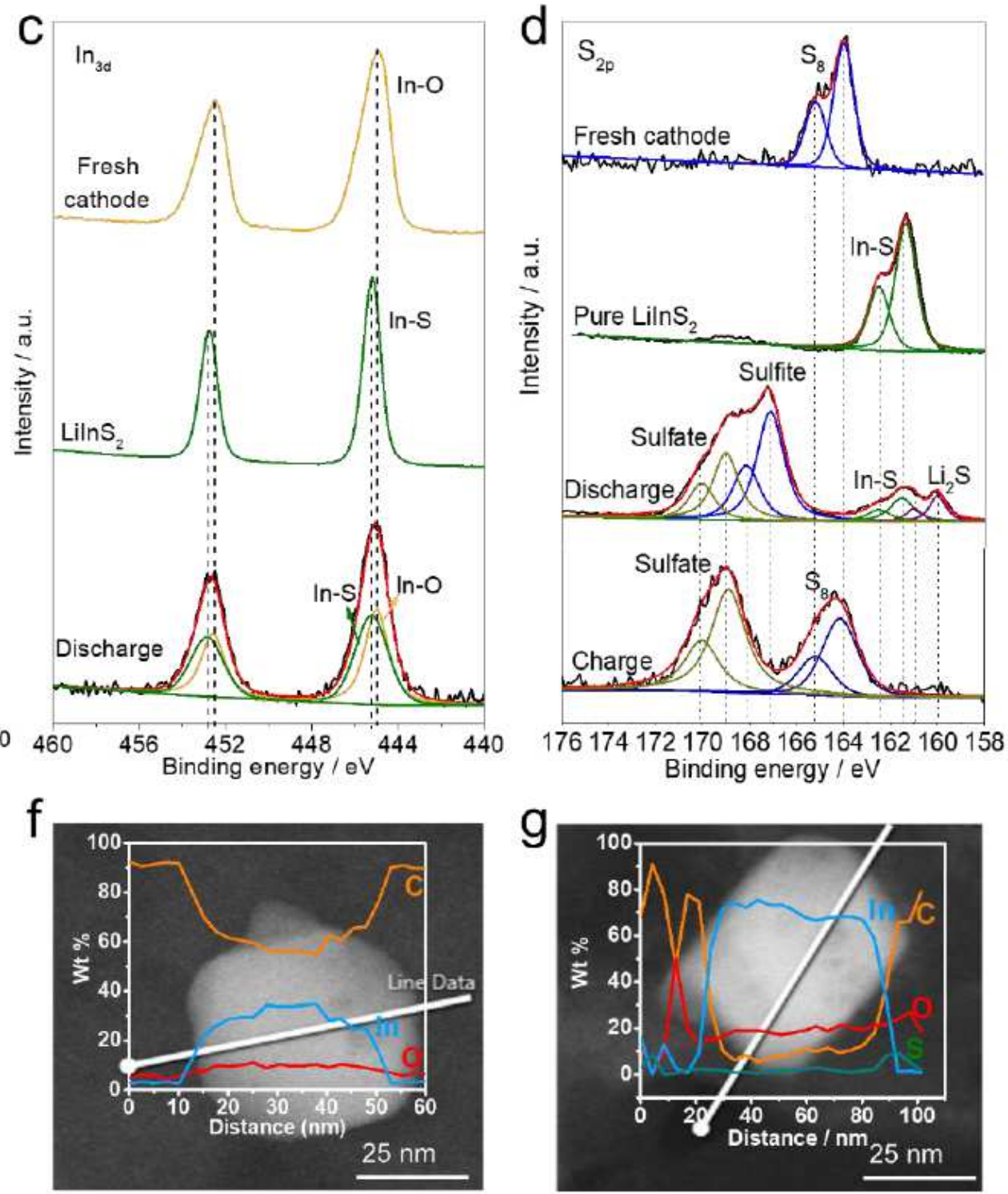

\section{Figure 5}

Conversion of polysulfide (Li2Sn) with LilnS2 as a catalysis intermediate. (a) XRD patterns of the prepared LilnS2; (b) Raman spectra (irradiated with $532 \mathrm{~nm}$ laser) of the synthesized LilnS2, LilnS2-free and LilnS2-based cathode (CP-LilnS2) discharged at 2.1 V; (c) XPS spectra for the 3d level of In: pristine In203, prepared LilnS2 and the In2O3 cathode in the fully discharged state; (d) S2p XPS spectra of fresh cathode, pure LilnS2 and the In203-catalyzed cathode in the fully discharged and charged state; (e) S2p XPS spectra of the In203-free cathode in the fully discharged and charged state; ADF-STEM images and corresponding line scan elemental mapping of (f) fresh In2O3 and (g) the In203-catalyzed cathode in the fully charged state. 

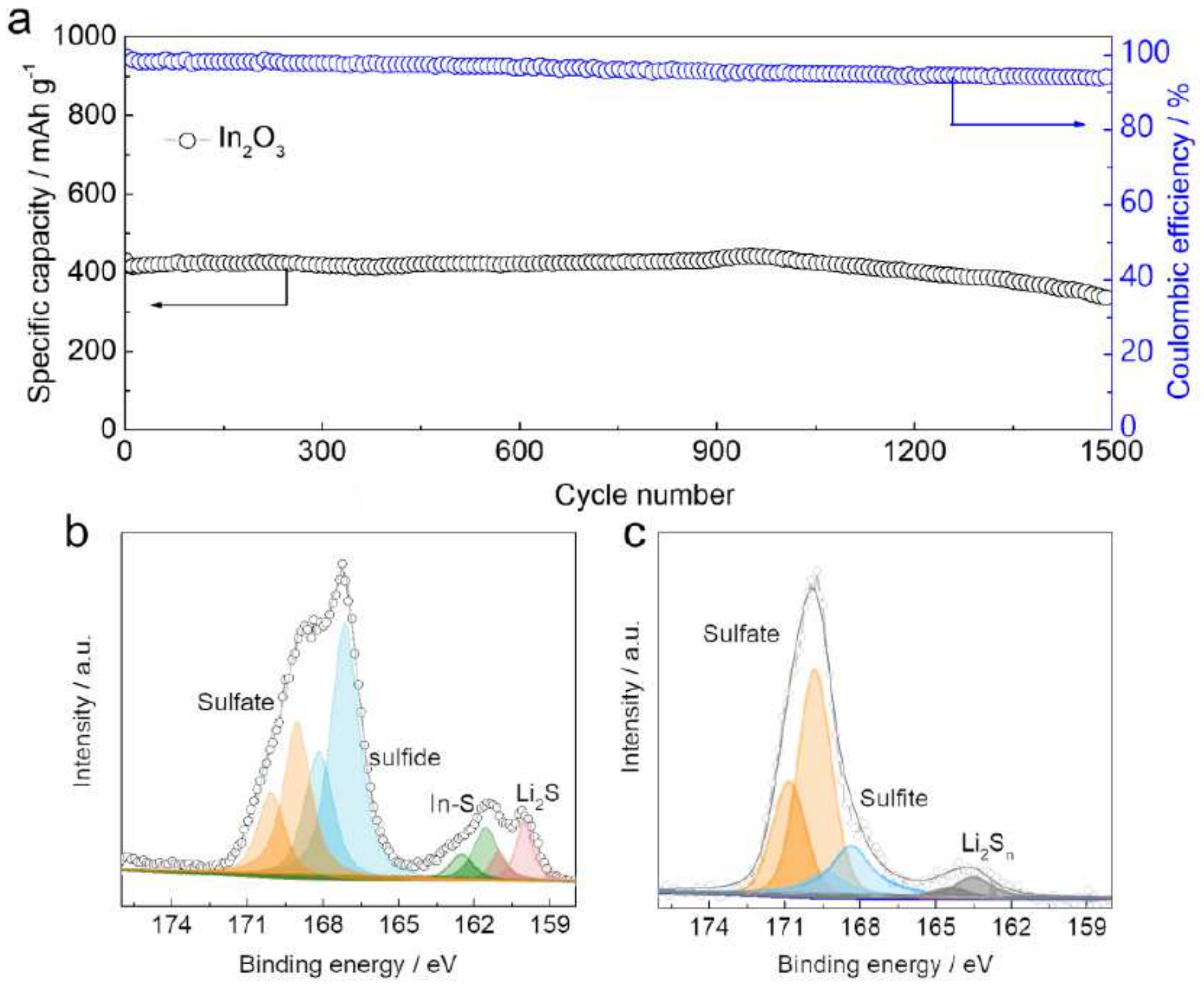

Figure 6

The deactivation of In203 catalyst. (a) cycling performance of In203-catalyzed battery at 4.0 C with a catalyst deactivation over 1000 cycles; S2p XPS spectra of In203-catalyzed cathode for the 1st (b) and 1000 th cycle (b) in the fully discharged states. 

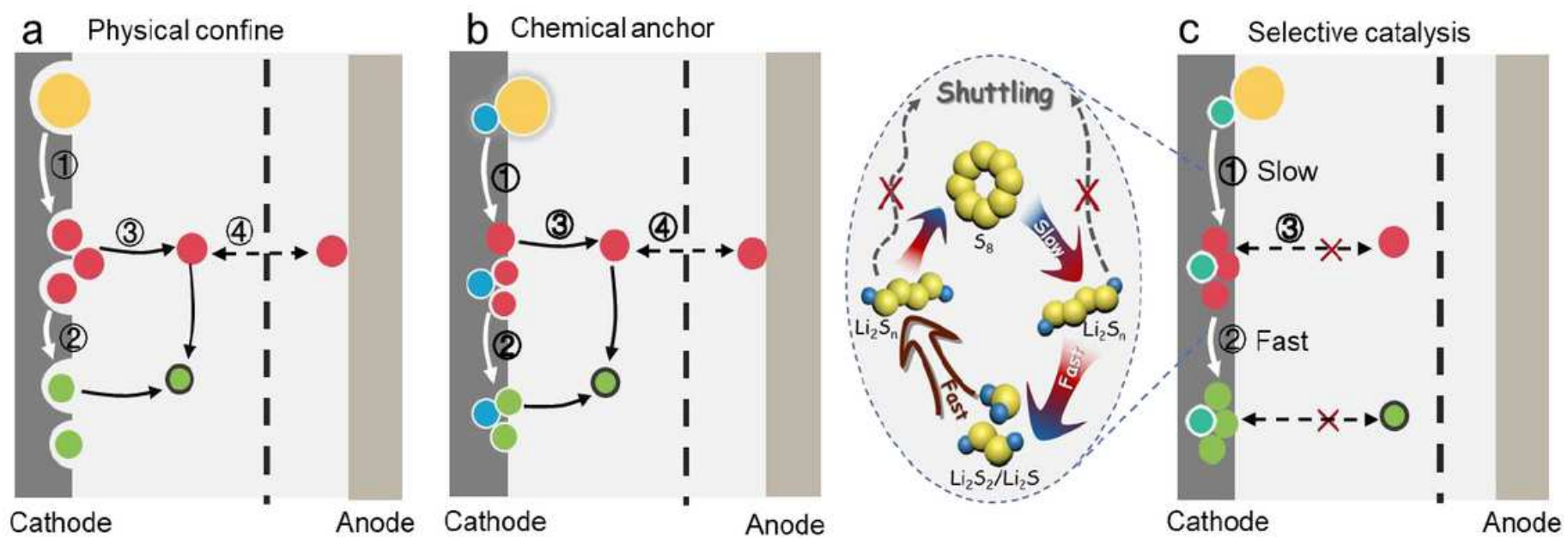

(1) Dissolution (2) Precipitation (3) Diffusion (4) Shuttling

Sulfur $\mathrm{LiPSs} \mathrm{Li}_{2} \mathrm{~S}$ Olrreversible sulfur Anchoring materials

$\ln _{2} \mathrm{O}_{3}$ catalyst

\section{Figure 7}

Scheme 1 Strategies to tackcle "shuttle effect" of soluble lithiium polysulfides (Li2Sn): physical confinement (a), chemical anchoring (b) and selective catalysis (c). Physical confinement and chemical anchoring are the most common ways to trap the soluble Li2Sn, working as follows: 1) the elemental sulfur gets electrons and forms Li2Sn on the conductive substrate; 2 ) the trapped Li2Sn are further reduced to Li2S on the conductive substrate; 3 ) other Li2Sn are released from the conductive substrate and dissolved in the electrolyte; 4) Some of the dissolved Li2Sn shuttle to the lithium metal side and then transfer back to the cathode side, resulting in the shuttle effect; the shuttled Li2Sn result in a continuous loss of active sulfur and the corrosion of $\mathrm{Li}$ anodes. Selective catalysis is proposed in this study as a fundamental remedy for reducing the accummulation of soluble Li2Sn and finally inhibiting the shuttle effect. For the discharging, the catalysis selectively slows down dissolution of elemental sulfur to Li2Sn while accelerates the deposition of Li2Sn into insoluble Li2S.

\section{Supplementary Files}

This is a list of supplementary files associated with this preprint. Click to download.

- ESINatureCatalysissubmit.docx 